\title{
KI A MIGRÁNS? A JELENKORI MAGYAR TÁRSADALMAT ÉRINTŐ MIGRÁCIÓS FOLYAMATOK ÖSSZEGZÉSE
}

\section{Gazsó Dániel}

\section{ÖSSZEFOGLALÓ}

A népvándorlás központi témává vált Magyarországon is az elmúlt évtizedekben. Jelentőségét az emigráció gazdasági és népesedési folyamatokra gyakorolt hatásaitól, az agyelszívástól, a fiatal, képzett munkaerő külföldre vándorlásától való félelmek mellett tovább fokozta a 2010-es évek közepén felerősödő menekülthullám. A kivándorlás mellett a bevándorlás kérdése is meghatározó lett a magyarországi migrációs politikában. Ezzel egyidejűleg a „migráns” kifejezés minden eddiginél tágabb és érzelmileg túlfütöttebb jelentéstartalommal terjedt el a hazai köztudatban. De ki a migráns valójában? Kik, honnan, mikor és miért jöttek Magyarországra? Mennyien maradtak itt? Mit jelez a számuk és a teljes népességen belüli arányuk nemzetközi viszonylatban? Hogyan alakult a magyarországi bevándorlás mérete és szerkezete a rendszerváltástól napjainkig? Mikor, hányan, hova és miért vándoroltak el Magyarországról? Közülük mennyien tértek vissza? A jelenkori magyar emigráció milyen szociodemográfiai jellemzőkkel bír? Milyen a kivándorlók kor és nemek szerinti összetétele, családi állapota, végzettsége? Melyek a legfőbb elvándorlási és visszavándorlási szándékot meghatározó vonzó és taszító tényezők Magyarországon? Tanulmányomban ezekre a kérdésekre keresem a választ. Célom, hogy a meglévő hazai és nemzetközi statisztikák, valamint a témában releváns kutatások eredményeinek másodelemzése révén átfogó és strukturált képet nyújtsak a jelenkori magyar társadalmat érintő migrációs folyamatokról.

Tárgyszavak: migráció, bevándorlás, kivándorlás, visszavándorlás, menekültügy, idegenellenesség, egyszerüsített honosítás 
Gazsó Dániel, Nemzetpolitikai Kutatóintézet, Nemzeti Közszolgálati Egyetem Államtudományi és Nemzetközi Tanulmányok Kar

E-mail: Gazso.Daniel@uni-nke.hu

\section{BEVEZETÉS}

A migrációs folyamatok legáltalánosabb és legegyszerübb megjelenítési formája a bevándorló külföldi állampolgárok és a kivándorló hazai állampolgárok számának hazai statisztikák alapján történő időrendi összevetéséből adódik (1. ábra). Ezzel azonban csupán egy felszínes képet kapunk a népvándorlás méretéről és tulajdonságáról. Egy mélyebb és átfogóbb összkép kialakitása viszont számos módszertani nehézségbe ütközik (Kováts és Várhalmi, 2014). Tanulmányom bevezetéseként ezeket a kérdéseket járom körül, tisztázva a későbbi fejezetekben használt alapfogalmakat.

\section{1. ábra: A be- és kivándorlás alakulása Magyarországon}

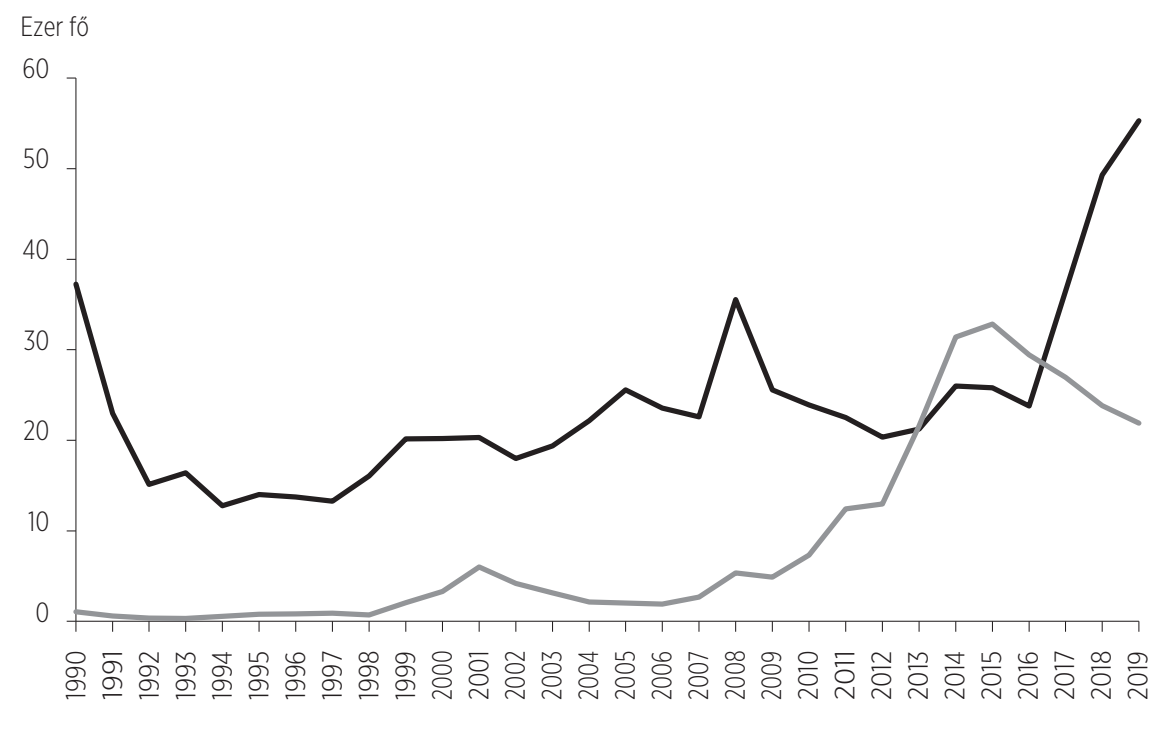

— Bevándorlók

— Kivándorlók

Forrás: Központi Statisztikai Hivatal, Demográfiai évkönyvek; STADAT-táblák. 
Az adminisztratív statisztikai adatok tekintetében az első kérdés, hogy hivatalosan ki számít migránsnak. Az elemzésem fókuszában álló nemzetközi népvándorlás, tehát az országhatárokat átívelő népmozgás esetében az egyik legfontosabb kritérium a célországban eltöltött idő. Egészen más következményekkel jár ugyanis az ideiglenes külföldi munkavállalás, az ingázás és a letelepedés mind egyéni, mind társadalmi szinten (Kováts és Soltész, 2018). Figyelembe véve, hogy a vándorlók között - legyen szó önkéntes vagy kényszerű migrációról - vannak, akik csupán tranzitországnak tekintik az őket befogadó államot, és amint lehetőségük nyílik rá, tovább vándorolnak, esetleg hazaköltöznek, vagy cirkuláris migrációt folytatnak, első lépésként a rövid és a hosszú távú migrációt kell megkülönböztetnünk egymástól. Ennek a legáltalánosabban elfogadott alapelvét az Egyesült Nemzetek Szervezetének (ENSZ) nemzetközi vándorlás méréséről szóló 1998. évi ajánlása adja, amelynek értelmében nemzetközi migráns az a személy, aki legalább 12 hónapra megváltoztatja a tartózkodási országát. A jelen tanulmányban megjelenített adminisztratív adatok két fő forrása az Európai Unió Statisztikai Hivatala (Eurostat), valamint a magyar Központi Statisztikai Hivatal (KSH) is ezt a meghatározást veszi alapul. Ezzel a definícióval azonban a migrációkutatás módszertani nehézségei korántsem oldódtak meg.

Egyrészt a bevándorlókat nemcsak állampolgárság szerint definiálhatjuk, hanem születési ország alapján is, ezzel azonban lényegesen eltérő adatokat kapunk. Magyarországi viszonylatban, ha az állampolgárság szerinti meghatározást követjük, számításunkból kimaradnak azok a külföldön született bevándorlók, akik korábban - főképp a 2011-ben bevezetett egyszerüsített honosítási eljárás lehetőségével élve - felvették a magyar állampolgárságot. Számuk 2015-ben megközelítette a 18 ezer főt, azaz az 1. ábrán azonos évre vonatkozóan megjelenített bevándorló külföldi állampolgárok összlétszámának több mint kétharmadát. Másrészt a kivándorlók mérése is dilemmákat vet fel (Kapitány és Rohr, 2014). A kivándorlási statisztikákban ugyanis csak azok jelennek meg, akik bejelentették a távozásukat valamilyen formában a hazai hatóságoknak. Ezt azonban a külföldre költözők csupán töredéke teszi meg, részben mert közülük sokan - kiváltképp az önkéntes gazdasági emigráció esetében - nem végérvényesen tervezik elhagyni az adott országot, hanem a későbbi hazaköltözés reményében. Következésképpen a befogadó országok tükörstatisztikái e tekintetben lényegesen magasabb értékeket mutatnak, mint a kibocsátó országok statisztikái (Blaskó

1 United Nations (1998): Recommendations on Statistics of International Migration. Revision 1, Statistical Papers, Series M, No. 58. Elérhető: unstats.un.org 
et al., 2014). Magyar vonatkozásban 2013 és 2015 között a hazai adatok alapján az 1. ábrán megjelenített kivándorlások száma évi 22 és 33 ezer között mozgott, míg ugyanabban az időben csak az európai célországokban több mint 85 ezer magyar állampolgárt regisztráltak évente (Gödri, 2018).

A nemzetközi vándorlás társadalmi hatásainak vizsgálatánál a bevándorlók különféle - állampolgárság, illetve születési ország szerinti - meghatározása, valamint a kivándorlók hazai statisztikákban megjelenő számának tükörstatisztikákkal való összevetése mellett fontos figyelembe venni a migráns népesség letelepedésére vonatkozó adatokat is. Tehát a migráció alakulását, trendjét, intenzitását mutató ún. flow adatok mellett - amelyek az 1. ábrán megjelennek - a migráns népesség állományára vonatkozó ún. stock adatokat is górcső alá kell venni. Utóbbinál szintén felmerülhet az állampolgárság vs. születési ország szerinti meghatározás dilemmája, ami különösen nagy jelentőséggel bír az egyes országokhoz kötődő migráns népesség számának és arányának megállapításakor. A Magyarországon életvitel-szerűen tartózkodó, Romániához kötődő népesség tekintetében például, ha pusztán az állampolgárság szerinti meghatározást vesszük alapul, akkor azt látjuk, hogy 2017-ben a tartózkodásra vagy letelepedésre jogosító engedéllyel rendelkező 151 ezer külföldi 16\%-a román állampolgár volt. A születési ország szerinti meghatározás figyelembevételével azonban - ha az ugyanabban az évben Magyarországon élő 370 ezer, külföldön született magyar állampolgárt is számításba vesszük - arra az eredményre jutunk, hogy az 521 ezer fős külföldi kötődésü lakosság 43\%-a Romániából származott (Kincses és Tóth, 2020).

A migrációs folyamatokról kialakítandó összkép szempontjából meghatározó továbbá a menekültügy, amely a fentiekben ismertetett bevándorlás kérdésétől külön kezelendő. E két, a közgondolkozásban sokszor összemosódó migrációs folyamat teljesen más befogadási elvek és jogszabályok mentén zajlik, ráadásul az érintett csoportok is lényegesen eltérnek egymástól. A menekültügy ismertetésénél elsőként és legáltalánosabban a menedékkérők számát, valamint az állampolgárságuk szerinti megoszlást használják. Ezek azonban vajmi keveset árulnak el a menekültügy valós helyzetéről és hatásáról. A kérelmezők ugyanis nem biztos, hogy meg is kapják a nemzetközi védelmet, azaz a menekült, oltalmazott vagy befogadott státust. Sokan még a hivatalos eljárás befejezése előtt elhagyják az országot, így a kérelmük el sem jut az elbírálásig. A fogalmi kereteket tisztázva menekültstátust az a külföldi állampolgár vagy hontalan személy kaphat, akinél a genfi egyezménynek megfelelően igazolható, hogy az üldözéstől való félelme megalapozott. ${ }^{2}$ Akit a származási országában nem fenyeget

${ }^{2}$ United Nations (1951): Convention Relating to the Status of Refugees. Genf, 1951. július 28. Elérhető: unhcr.org 
személyes üldözés, de fennáll a veszélye, hogy visszatérése esetén súlyos sérelem érné, oltalmazott státust kaphat, továbbá azoknak, akik sem menekült, sem oltalmazott státusra nem jogosultak, de a származási országukba átmenetileg nem küldhetők vissza, mert ott halálbüntetésnek, kegyetlen vagy megalázó bánásmódnak vagy büntetésnek lennének kitéve, befogadott státus adható (Gödri, 2018). Magyarországon a KSH adatai alapján 2015-ben - amikor a menedékkérők száma kiemelkedően magas, több mint 177 ezer volt - menekült, oltalmazott vagy befogadott státust összesen alig több mint 508 fő kapott. Utóbbiak száma 2016-ban még ennél is alacsonyabb, 432 volt (KSH, STADAT-táblák).

Az eddigiekben tárgyalt adminisztratív statisztikai adatokkal kapcsolatos dilemmák mellett a népvándorlás mélyebb megértésére irányuló kérdőíves (survey) kutatások még összetettebb módszertani nehézségekbe ütköznek. Migrációkutatás esetén - mivel a célcsoportot lényegében egy mozgó népesség alkotja - nem egyértelmü az alapsokaság meghatározása. Következésképpen a többségi társadalom vizsgálatára bevett mintavételi módszerek alkalmazása a legtöbbször ellehetetlenül. Ez jelentősen korlátozza a célcsoportok kvalitatív megismerését, a szociodemográfiai jellemzőik, a helyváltoztatásuk mögött álló motivációik feltárására irányuló kutatások érvényességét és megbízhatóságát (Várhalmi és Kováts, 2014).

A következőkben a jelenkori magyar társadalmat érintő migrációs folyamatokat a meglévő hazai és nemzetközi statisztikák, valamint a nagymintás kutatások eredményei alapján ezen módszertani nehézségek és mérési korlátok tudatában kísérlem meg összegezni. A bevándorlás, kivándorlás és visszavándorlás ismertetése során külön kitérek majd a 2010-es évek közepén tapasztalt menekülthullám következményeire, az idegenekkel szembeni attitüdök hazai és nemzetközi tendenciáira, az évtized végére felerősödő ukrán emigrációra és annak kárpátaljai vetületeire, valamint az egyszerűsített honosítási eljárás népvándorlási adatokra gyakorolt közvetett hatásaira.

\section{BEVÁNDORLÁS}

A külföldi állampolgárok bevándorlását az 1989-es rendszerváltást követő bő húsz esztendőben alapvetően a négy szomszédos országból - Romániából, Szerbiából, Ukrajnából és Szlovákiából - áttelepültek száma és összetétele határozta meg. Még a 2000-es évek elején is ezekből az országokból származott a bevándorló külföldi állampolgárok 70\%-a (Gödri, 2018). Az első nagyobb bevándorlási hullám - amikor főként Romániából települtek át - 1988 és 1991 között le- 
csengett. Ezt követően a bevándorló külföldi állampolgárok száma alacsonyabb szinten mozgott, évi 13-16 ezer fö között, csak az ezredforduló körüli években érte el a 20 ezer főt, majd évi 18-26 ezer fő között ingadozva stabilizálódott. Kivételt jelentett ez alól 2008, amikor a bevándorlók száma hirtelen megugrott, és meghaladta a 35 ezer főt, valamint a 2010-es évek vége, amikor három év leforgása alatt a számuk 26 ezerről 55 ezerre nőtt (1. ábra). A 2008-as, kimagasló értéket elsősorban a szabad mozgás és tartózkodás jogával rendelkező személyek beutazására és tartózkodására vonatkozó 2007. évi l. törvény idézte elő. ${ }^{3}$ A 2007. július 1-jén hatályba lépett új jogszabály leegyszerüsítette az Európai Gazdasági Térség (EGT) állampolgárai és harmadik országbeli családtagjai számára az állandó lakhely létesítésének feltételeit Magyarországon. 2008-ban közel 20 ezer fő élt ezzel a lehetőséggel. Ez azonban nem jelenti azt, hogy közülük mindenki itt is maradt, a lakcímlétesítés sok esetben nem járt együtt a tényleges letelepedéssel (Gödri, 2015). A bevándorló külföldi állampolgárok számának 2010-es évek végi ugrásszerü megnövekedése elsősorban az egyre nagyobb méreteket öltő ukrán emigrációs hullámmal függ össze, ami nemcsak Magyarországot érintette, hanem az egész kontinenst. A 2010-es évek második felében az Európai Unió tagállamai évente több mint félmillió első tartózkodási engedélyt adtak ki ukrán állampolgárok részére, 2019-ben 757 ezret, ami az EU27 területén kiadott összes tartózkodási engedély egynegyedét tette ki (Eurostat, 2020).

Az ukrán elvándorlás tömegessé válását nem pusztán a 2010-es évek közepén kialakult orosz-ukrán konfliktus eredményezte. A Szovjetunió felbomlásával 1991-ben függetlenné vált Ukrajna a rendszerváltásból fakadó nehézségeket még nem heverte ki a 2008-as világválság kirobbanásáig. A gazdasági depressziót fokozta a gyenge államiság és az abból fakadó társadalompolitikai válságok: a 2004-2005-ös Narancsos Forradalom és a 2013-2014-es Méltóság Forradalma. Mindez már a 21. század első évtizedében is jelentős népességcsökkenéshez vezetett. 1992 és 2013 között a világ országai közül Ukrajna veszitett a legtöbbet a lakosságából, tehát még a 2014 márciusában kirobbant kelet-ukrajnai háborút megelőzően, amely tovább fokozta az elvándorlás mértékét (Karácsonyi és Kincses, 2020). Míg 2010 előtt Németország, Olaszország, Spanyolország, valamint a visegrádi négyek közül Csehország fogadta be a legtöbb ukrán migránst, addig a 2010-es években Lengyelország lett számukra az elsődleges célország. Magyarországon a bevándorló ukrán állampolgárok száma 2014-ben még ezer fő volt alatt volt, 2017-ben több mint hatezer, 2018-ban megközelí-

\footnotetext{
${ }^{3}$ A szabad mozgás és tartózkodás jogával rendelkező személyek beutazásáról és tartózkodásáról szóló 2007. évi l. törvény teljes szövege elérhető a net.jogtar.hu weboldalon.
} 
tette a 17 ezret, 2019-ben pedig már meghaladta a 21 ezret. Ez azt jelenti, hogy 2019-ben tíz magyarországi bevándorlóból csaknem négy ukrán állampolgár volt. Az egyre nagyobb méreteket öltő ukrán emigrációs hullám természetesen hatással volt a Kárpátalján elő magyar kisebbségi közösség népességszámának alakulására is. Utóbbit azonban a hivatalos statisztikai adatok hiányában nehéz pontosan meghatározni. A függetlenné vált Ukrajnában az első és máig utolsó népszámlálást 2001-ben tartották. Az ebből fakadó adathiány egész Európában egyedülálló. 2001-ben Kárpátalja népességének 12,1\%-a, összesen 151,5 ezer fő vallotta magát magyar nemzetiségűnek. A 16 ével későbbi, Kárpátalja 111 magyarlakta településére kiterjedő, több mint 23 ezer személy adatait rögzítő SUMMA 2017-kutatás eredményei alapján a régióban élő magyarok száma 131 ezer főre becsülhető, ami a 2001-es népszámlálási adatokhoz viszonyítva megközelítőleg 21 ezer fős fogyást jelent (Ferenc és Kovály, 2020). A felmérést végző kutatók értelmezése szerint ezt a nagyszámú népességcsökkenést 70\%-ban az elvándorlás, 30\%-ban a természetes fogyás okozta, míg az asszimiláció, tehát az etnikai klasszifikáció alakulása ez esetben nem számottevő. A kárpátaljai magyarok népességcsökkenéséről még drasztikusabb képet nyújtanak a magyarországi bevándorlási statisztikák. Ezzel kapcsolatban azonban a fenti kutatás szerzői külön felhívják a figyelmet a cirkuláris migráció, azaz a rendszeres oda-vissza vándorlás jelentőségére. Mint azt a beérkező válaszokból megállapították, 2016-ban a különböző célú ideiglenes, határon átívelő vándorlás mintegy 28 ezer magyar embert tartott mozgásban Kárpátalján. Mindez a kisebbségi közösség magas szintű rugalmasságát jelzi, ami nemcsak a vándorlási hajlandóságot, de az otthonmaradás esélyeit is növelheti. A megélhetési nehézségek következtében egyre gyakoribbá vált külföldi munkavállalások láthatóan nem vezetnek feltétlenül hosszú távú vagy akár végérvényes emigrációhoz.

A bevándorlás szerkezetét illetően a Magyarországra bevándorló külföldi állampolgárok származási ország szerinti összetétele jelentősen átalakult az elmúlt évtizedekben. Míg az 1990-es és 2000-es években a bevándorlók többsége a fent említett négy szomszédos országból érkezett, addig a 2010-es évek elejére e csoport száma és aránya is jelentősen lecsökkent: 2014 és 2016 között már csak a bevándorlók egynegyedét adta. E változásnak több oka is van. Egyrészt Magyarország Európai Unióhoz való csatlakozása, valamint a fentebb részletezett, 2007. július 1-jétől hatályos új idegenjogi törvény következtében megnőtt a régi tagállamokból, elsősorban Németországból érkezők száma. Mindemellett 2006-tól az ázsiai országokból is, főként Kínából egyre többen jöttek Magyarországra. Mindez a bevándorlók származási országok szerinti diverzifikálódását okozta. Másrészt az Európai Unió keleti bővülése új útvonalakat nyitott meg a 
szomszédos országok vándorló népessége előtt. Részben ennek köszönhetően a térség egyik legnagyobb kibocsátó országából, Romániából 2015-re a Magyarországra érkezők aránya a korábbi több mint 50-ről 20\% alá csökkent. Ezzel egy időben a nyugat- és dél-európai országokban tömegesen jelentek meg a román bevándorlók. Továbbá a szomszédos országok állampolgárainak bevándorlására vonatkozó hazai statisztikákat jelentősen befolyásolta a 2011-ben bevezetett, egyszerüsitett honosítási eljárás, amelynek következtében - mint arra fentebb is utaltam már - egyre nagyobb számmal érkeztek olyan külföldön született bevándorlók, akik magyar állampolgársággal (is) rendelkeztek, így az állampolgárság meghatározására alapozott bevándorlási statisztikákban nem jelentek meg.

Az egyszerűsített honositási eljárást lehetővé tevő 2010. évi XLIV. törvény migrációs adatokra gyakorolt közvetett hatásainak elemzésénél a honosítottakat célszerủ legalább három szempont szerint külön megvizsgálni: 1.) a honosítási eljárások összértékét; 2.) a bevándorló külföldön született magyar állampolgárok számát; valamint 3.) a Magyarországon élő külföldi állampolgárok honosítását figyelembe véve. ${ }^{4}$ Az első szempont szerint 1993 és 2015 között összesen 843 ezer fő kapott magyar állampolgárságot határon belül és határon túl, ebből 708 ezer az egyszerűsitett honosítási eljárás bevezetése utáni időszakra tehető (KSH, 2017). Egyértelműen látszik, hogy az új jogszabály milyen nagy jelentőséggel bír a honosítások számát illetően. A második szempontot figyelembe véve a bevándorló külföldön született magyar állampolgárok száma 2012-ben és 2013-ban alig több mint nyolcezer volt, míg 2014-ben és 2015-ben meghaladta a 17 ezret. Ezt követően ugyan csökkent a számuk, de még az évtized második felében is évi 10 ezer fölött maradt (2. ábra). Ez a nagymértékű növekedés szintén az egyszerüsitett honosítási eljárás következményeként értelmezhető.

A harmadik szempont tekintetében Magyarországon az állampolgársági törvény 1993. évi bevezetésétől 2017 végéig összesen több mint 203 ezer bevándorló kapott magyar állampolgárságot, egyharmaduk 2011-et - az új állampolgársági törvény hatálybalépését - követően. Részben ennek a jogszabálynak köszönhetően 2012-ben Magyarország európai összehasonlításban első helyen állt a honosítási ráta, azaz az országban tartózkodó külföldi állampolgárságú népesség év eleji létszámához viszonyított állampolgárságot szerzők arányának tekintetében (Gödri, 2018). Itt azonban fontos hangsúlyozni, hogy míg az európai uniós tagországokban a honosítottak több mint 80\%-a az unión

\footnotetext{
${ }^{4}$ Az egyszerüsített honositási eljárás alapfeltételeit a magyar állampolgárságról szóló 1993. évi LV. törvény módositásáról szóló a 2010. évi XLIV. törvény 2. § (2) a következőképp írja elő: “[...] kedvezményesen honositható az a nem magyar állampolgár, akinek felmenője magyar állampolgár volt vagy valószínüsíti magyarországi származását, és magyar nyelvtudását igazolja." A törvény teljes szövege elérhető a net.jogtar.hu weboldalon.
} 
kivülről származik, addig Magyarországon ez az arány - Románia 2007-es EU-s csatlakozását követően - mindössze 20-30\%. Az Európán kívüli országokból származó bevándorlók közül kevesebb mint 7000 fő kapott magyar állampolgárságot 1993 és 2019 között. Mindez a vérségi elv (ius sanguinis) dominanciájára, valamint az eltérő származású bevándorlókkal szembeni szigorú honosítási feltételekre utal.

2. ábra: A Magyarországra bevándorló külföldi állampolgárok és a bevándorló külföldön született magyar állampolgárok

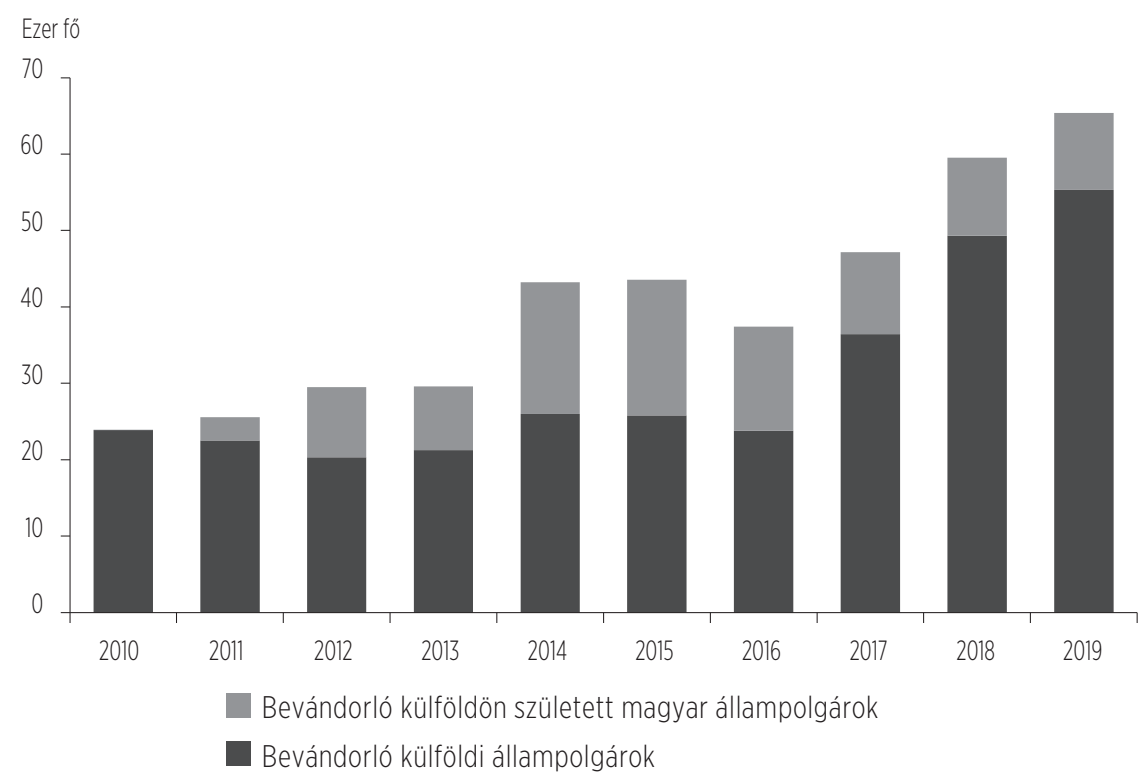

Forrás: KSH, STADAT-táblák.

A migrációs folyamatok hatáselemzésénél a honosítási eljárások mellett meghatározó még az országban tartózkodásra vagy letelepedésre jogosító engedélyek kiadása. Az e csoportba tartozó Magyarországon élő külföldi állampolgárok származási ország szerinti összetétele - a bevándorló külföldi állampolgárok szerkezetéhez hasonlóan - a 2010-es években jelentősen átalakult. Míg a 2000es években 56-68\%-uk a négy szomszédos ország, Románia, Szerbia, Ukrajna és Szlovákia valamelyikének állampolgára volt, addig ez az arány 2017-2018-ban nem érte el a 30\%-ot sem, és még az ukrán bevándorlási hullám felerősödésének hatására is csupán 34\%-ra emelkedett az évtized végére (3. ábra). 


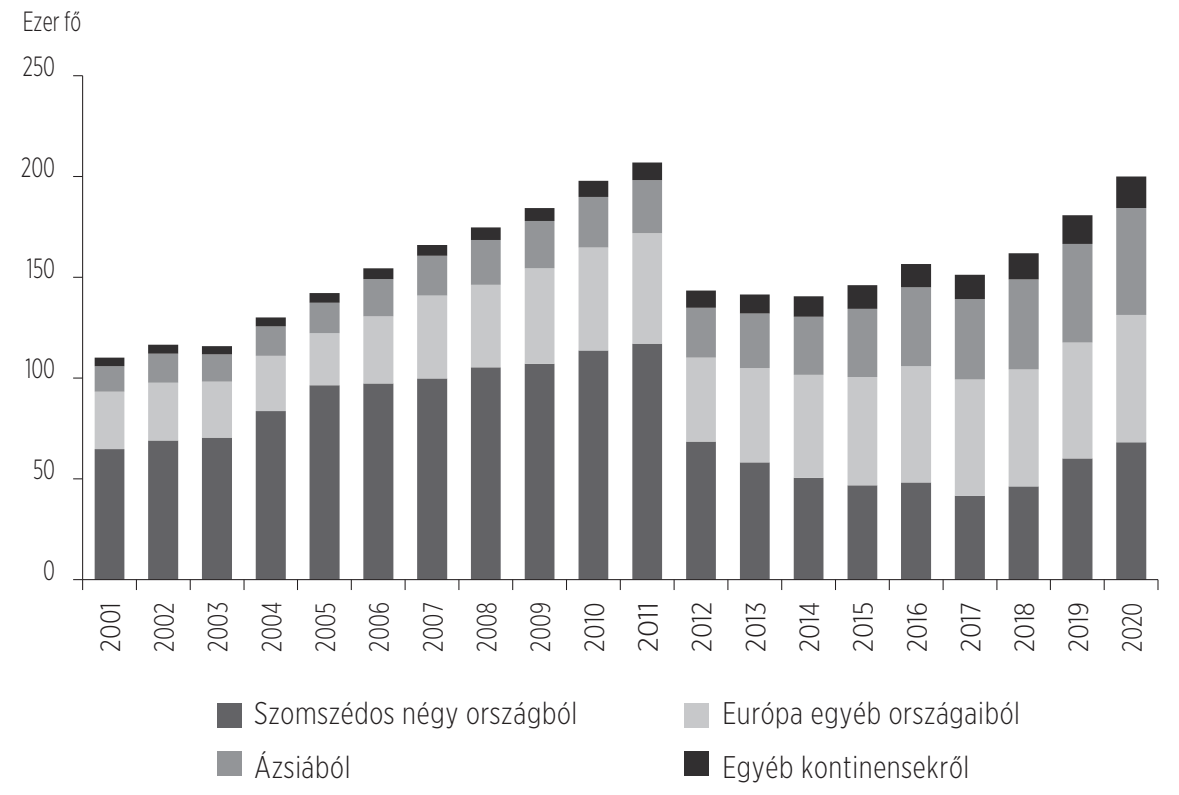

Forrás: KSH, STADAT-táblák.

Míg a bevándorlók ezer lakosra számított aránya nemzetközi összehasonlításban a nyugat-európai országok többségében 5, sőt némely államban 10\%。 feletti, addig Magyarországon az ezredforduló óta 1,8-2,6\% között ingadozik, és még a bevándorló külföldön született magyar állampolgárokkal együtt is csak ritkán érte el a 4\%o-et (Gödri, 2018). Kivételt jelent ez alól a 2008-as év, amikor a 2007. évi I. törvény hatályba lépésének következtében 3,5\%o-re ugrott, valamint a 2010-es évek vége, amikor a nagyszámú ukrán bevándorlás miatt meghaladta az 5\%o-et is. A tartózkodásra vagy letelepedésre jogosító engedéllyel rendelkező külföldi állampolgárok népességen belüli aránya is jóval alacsonyabb Magyarországon, mint a legtöbb európai országban. 2017-ben - tehát még az ukrán bevándorlás tömegessé válása előtt - míg az EU28 népességének 7,5\%-a volt külföldi állampolgár abban az országban, amelyben élt, addig Magyarországon ez az érték csupán 1,5\%, összesen 151 ezer fő volt (Eurostat, 2018). Megjegyzendő továbbá, hogy a legtöbb tagországban a külföldi állampolgárok zöme harmadik országbeli volt, míg Magyarországon ez az arány abban az évben mindössze 44\%-ot tett ki. Ez azt jelenti, hogy az életvitelszerüen itt tartózkodó migránsok 
többsége Európából, azon belül is a környező országokból származik (Kincses és Tóth, 2020). 2017-ben az 521 ezer fős külföldi kötődésű lakosságból - azaz a külföldi állampolgárok és a külföldön született magyar állampolgárok összességéből - 206 ezer román, 65 ezer ukrán, 40 ezer szerb, 27 ezer szlovák kötődéssel rendelkezett (4. ábra). Következésképpen a bevándorlás Magyarországon jelentős demográfiai változást nem idézett elő.

4. ábra: A négy szomszédos országhoz kötődő népesség területi eloszlása Magyarországon 2017-ben

Román kötődésủ népesség

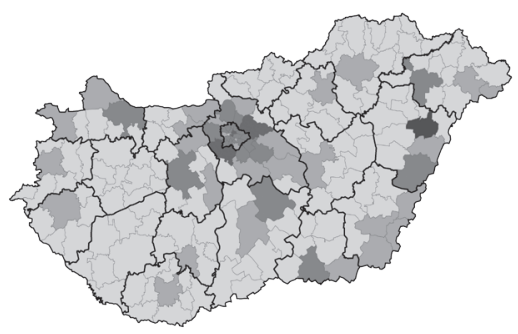

Szerb kötődésű népesség

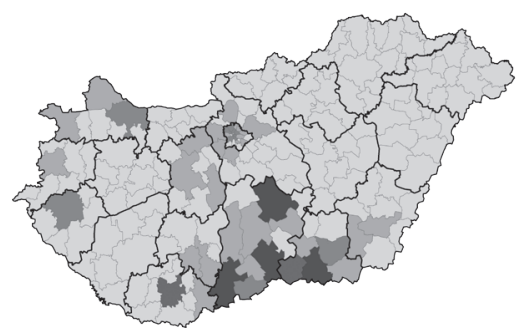

Ukrán kötődésű népesség

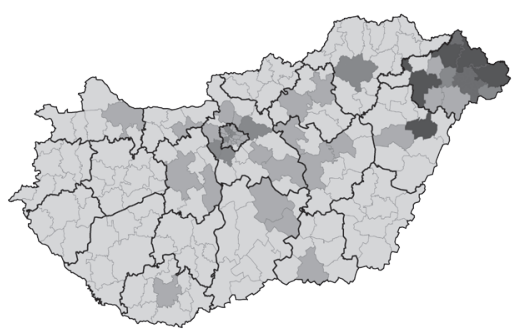

Szlovák kötődésű népesség

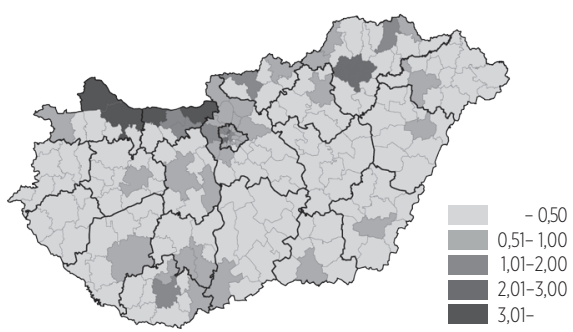

Forrás: Kincses, 2019, 4760.

\section{MENEKÜLTÜGY}

Az eddigiekben tárgyalt, a Magyarországra bevándorló, esetlegesen itt letelepedett, illetve tartózkodási engedéllyel rendelkező vagy honosított külföldi állampolgárok kérdése nem összekeverendő a menekültek ügyével. Utóbbiaknál lényegesen eltérőek - mint azt a fogalmi keretek tisztázásánál hangsúlyoztam a migráció motivációi, valamint a célországba való bevándorlás és tartózkodás feltételei, ezért a velük kapcsolatos kérdéseket külön kell kezelni. 
A menekültügy a 2010-es évek közepétől - az észak-afrikai és közel-keleti országokban végbemenő forradalmi láncreakció, az ún. arab tavasz következtében kialakult migrációs hullámok hatására - központi témává vált Európában. Az ENSZ Menekültügyi Főbiztosának (UNHCR) 2014-es jelentése szerint a fejlett ipari országokban 22 éve nem kértek olyan nagy számban (866 ezer fő) menedéket, mint abban az évben (UNHCR, 2014). Az őket befogadó országok rangsorában első helyen Németország (173 ezer fő), második helyen az Egyesült Államok (121 ezer fő), harmadik helyen Törökország (87 ezer fő) állt.

Magyarországon 2000 és 2017 között több mint 320 ezer menedékkérelmet nyújtottak be, 84\%-át 2013 és 2016 között. A menedékkérők száma 2012-ben még alig haladta meg a kétezer főt, 2013-ban 19 ezer fő, 2014-ben már több mint 42 ezer fő volt, 2015-ben pedig elérte a 177 ezer főt. Ezt követően a kérelmek száma jelentősen visszaesett, 2016-ban a 30 ezret sem érte el, 2017-ben a háromezret is alig haladta meg (5. ábra).

\section{5. ábra: A Magyarországra érkezett menedékkérők száma}

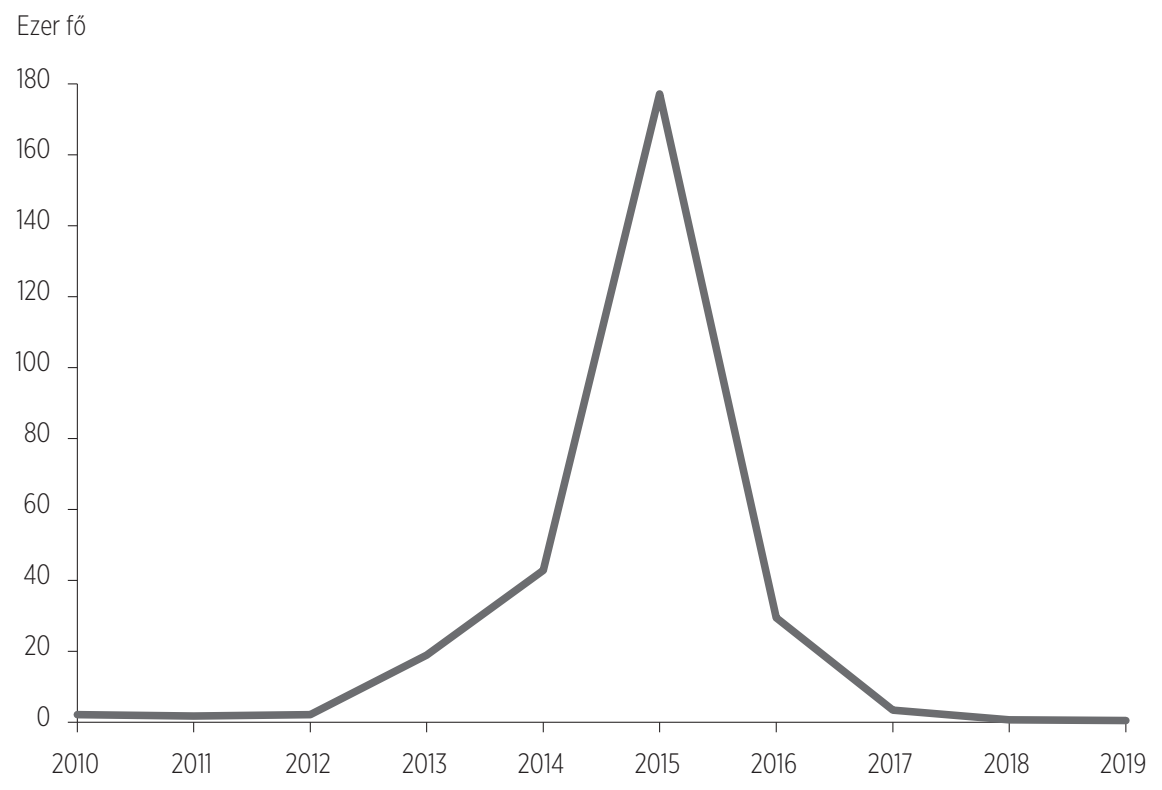

Forrás: KSH, STADAT-táblák. 
A kérelmet benyújtók származási ország szerinti összetételét tekintve az 1990-es években a dél-szláv háborúk elől menekülők érkeztek a legtöbben az országba, az ezredforduló idején viszont egyre nagyobb számban jelentek meg az Európán kívüliek. A 2000-es évek elején az afgán, iraki és bangladesi állampolgárok voltak többségben. 2008-ban és 2009-ben a koszovóiak képezték e csoport legnagyobb részét, míg 2010-ben és 2012-ben ismét az afgánok. A különféle hírforrásokban sokat emlegetett, polgárháború elől menekülő szíriaiak tömegesen 2014-ben jelentek meg először Magyarországon (mintegy hétezer fő). 2015-ben a számuk megközelítette a 65 ezret. A szíriaiak mellett a menekülthullámnak ebben a kritikus évében is nagy számban érkeztek afgán (több mint 46 ezer fő) és koszovói (több mint 24 ezer fő) kérelmezők (6. ábra).

6. ábra: A Magyarországra érkezett menedékkérők állampolgárság szerinti megoszlása 2015-ben

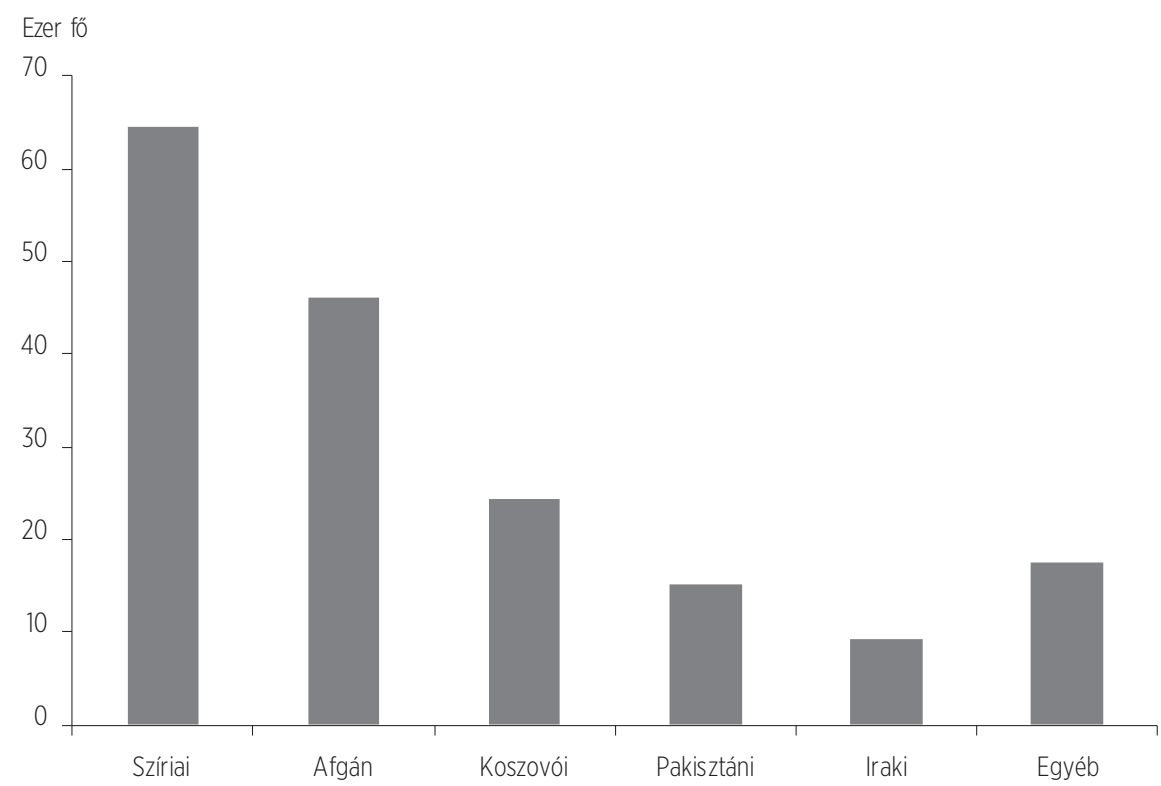

Forrás: KSH, STADAT-táblák.

A menedékkérők száma Magyarországon 2000 és 2019 között ugyan meghaladta a 300 ezret is, menekült, oltalmazott vagy befogadott státust ez idő alatt kevesebb mint 10 ezer fő kapott. Ennek egyrészt az az oka, hogy a kérelmezők többsége még az eljárás befejezése előtt elhagyta az országot. Európai 
Összehasonlításban itt a legalacsonyabb azoknak a menekültügyeknek az aránya, amelyek eljutnak a döntéshozatalig (KSH, 2016). A menedékkérők többsége ugyanis nem itt kíván letelepedni, Magyarországot csak tranzitországnak tekinti, és még a hivatalos eljárás befejezése előtt továbbvándorol. Másrészt, még ha el is jutnak a kérelem elbírálásáig, a pozitív döntések aránya e tekintetben igen alacsony. A 2014-2015-ös menekülthullámot követő évben Németországban, Svédországban és Ausztriában az elbírált menedékkérelmek 69-72\%-ában született első fokon pozitív döntés, Magyarországon ez az arány mindössze 8\% volt. 2016. január 1-jén a tartózkodásra jogosító menekült, illetve oltalmazott státussal rendelkező személyek száma 408 ezer volt az Európai Unió tagállamaiban, azaz a teljes népesség 0,08\%-a, addig Magyarországon mindössze 4400 fö, az összlakosság 0,04\%-a (KSH, 2016).

\section{IDEGENELLENESSÉG}

Magyarországról általánosan megállapítható, hogy a migrációs folyamatok globális áramlatai ugyan hatnak rá, de befogadó országként nemzetközi összehasonlításban minden szempontból alacsony értékeket mutat. A bevándorló, illetve a tartózkodásra vagy letelepedésre jogosító engedéllyel rendelkező külföldi állampolgárok, valamint a menekült, oltalmazott vagy befogadott státust kapott személyek száma és népességhez viszonyított aránya is elmarad az európai átlagtól. Arról a kevés migránsról pedig, aki életvitelszerüen itt tartózkodik, általánosan elmondható, hogy arányaiban magasabb iskolai végzettséggel és nagyobb vállalkozó kedvvel rendelkezik, mint a bennszülött szomszédjaik. Ez főképp a migráció szelekciós mechanizmusának és a bevándorlók fiatalabb korösszetételének köszönhető. Bizonyos származási csoportok - különösen a vietnámiak, kínaiak és törökök - körében továbbá kiugróan magas a vállalkozók aránya (Gödri, 2017). Mindezzel szemben, mintegy paradox módon az idegenellenesség igen nagymértékü a magyar lakosság körében (Sik et al., 2016; Csepeli és Örkény, 2017; Barna és Koltai, 2018). A TÁRKI Omnibuszkutatások eredményei szerint az idegenekkel szembeni negatív attitűd ráadásul nem új jelenség Magyarországon (7. ábra). Már a rendszerváltást követően növekedésnek indult (1992 és 1995 között 15-ről 40\%-ra ugrott), majd ingadozott (1996-ban visszaesett 19\%-ra, míg 2001-ben elérte a 43\%-ot), stagnált (2002-2011-ben 26 és 32\% között mozgott), 2012 után pedig újra növekvő tendenciát mutatott (2016-ban elérte az 53\%-ot). 
Az ezredfordulót követő két évtizedben a magyar népesség bevándorlókkal kapcsolatos attitűdjeiben a legnagyobb változás az Európán kívüli szegényebb országokban élő emberek befogadásának megítélésében volt tapasztalható. A European Social Survey (ESS) erre vonatkozó adatai alapján e csoport tagjainak bevándorlását 2002-ben a megkérdezettek csupán egynegyede utasította el teljes mértékben, 2015-ben már a 48\%-a (Barna és Koltai, 2018).

\section{7. ábra: Az idegenellenesség mértékének alakulása Magyarországon}

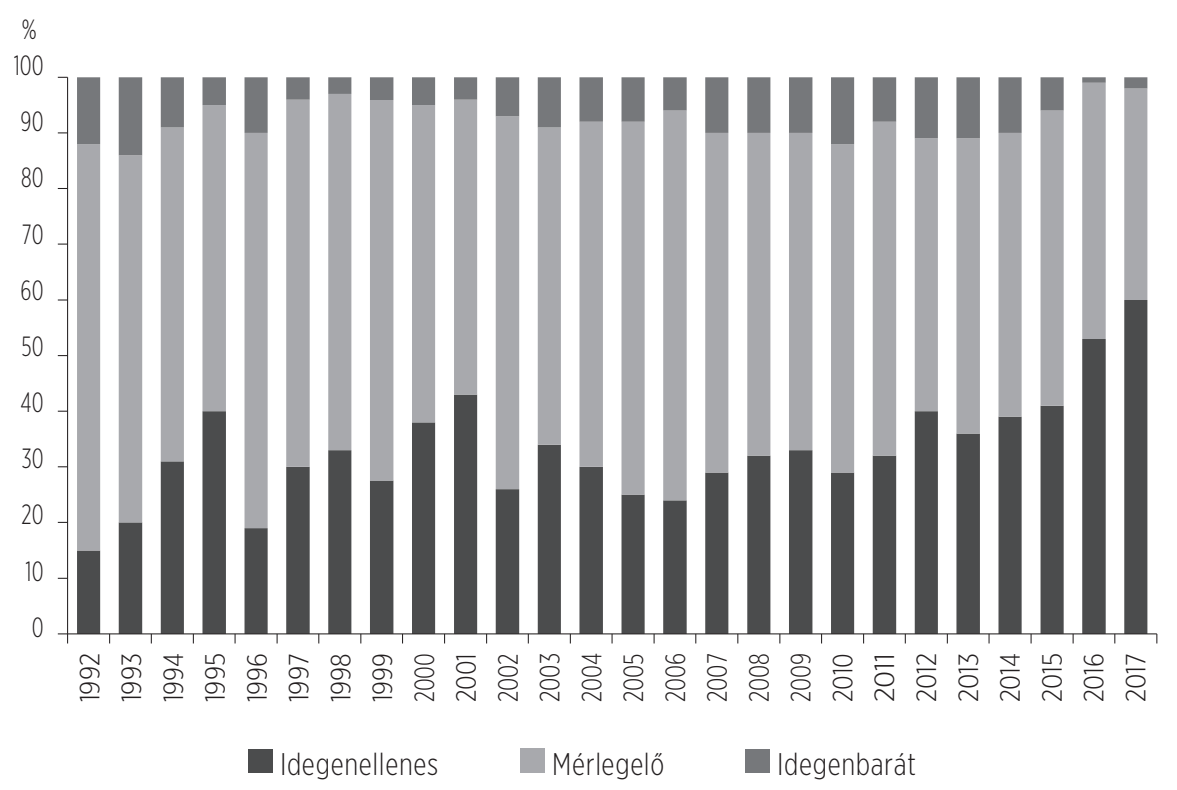

Forrás: TÁRKI, Omnibusz. ${ }^{5}$

Az idegenellenes, illetve az idegenbarát attitüdök kialakulásában és fellelhetőségében leginkább a lakóhely, az iskolai végzettség, a politikai orientáltság, a vallásosság és az életkor játssza a fontos szerepeket. A visegrádi országokra kiterjedő Central European Opinion Research Group (CEORG) reprezentatív mintákon végzett, 2015-ös kutatásának Magyarországra vonatkozó eredményei az mutatják, hogy az idegenellenességet nyíltan vállalók aránya magasabb a

\footnotetext{
${ }^{5}$ Az ábrán megjelenített TÁRKI Omnibusz-kutatások adatainak begyüjtésekor a következő kérdést és válaszlehetőségeket adták meg: Ön szerint be kell-e fogadni a menekülöket? 1.) Igen, minden menekülőt be kell fogadni (idegenbarát álláspont); 2.) Van, akit be kell fogadni és van, akit nem (mérlegelő álláspont); 3.) Senkit sem szabad befogadni (idegenellenes álláspont).
} 
megyeszékhelyeken (50\%), Dél- és Észak-Alföldön (40-40\%), a Jobbik- és a Fidesz-szavazók körében (50, illetve 41\%), a kevésbé képzettek között, akik legfeljebb általános iskolai vagy középiskolai végzettséggel rendelkeznek (44, illetve 42\%), valamint a 38-47 éves korosztályban (43\%). A politikai aktivitás tekintetében hangsúlyozandó továbbá, hogy a politikából kiábrándultak azok, akik a legnagyobb arányban nem engednének be egyetlen menedékkérőt sem az országba. Ezzel szemben az idegenbarátok (akik aránya lényegesen alacsonyabb, a magyarországi minta mindössze 4\%-a) az átlagnál nagyobb valószínüséggel Nyugat-Dunántúlon (14\%), a 67 éves vagy annál idősebb korosztályban (12\%), a heti rendszerességgel templomba járók körében (10\%), valamint a Budapesten kívüli városokban (7\%) találhatóak. E kutatási eredményeket összegző tanulmány szerzői a korábbi felmérések eredményit is figyelembe véve arra a megállapításra jutottak, hogy az idegenellenesség leginkább a társadalmi-gazdasági szempontból vesztes csoportokra, a munkaerőpiacról kiszorultakra, alacsonyabb - legfeljebb általános iskolai - végzettséggel rendelkezőkre, nehéz anyagi körülmények között élőkre jellemző (Sik et al., 2016). Ennek az általános megállapításnak a kiegészítéseként megjegyzendő, hogy az idegenellenességre, illetve tágabb értelemben véve a másság elutasítására való hajlamot nem pusztán a szegénység vagy a jólét hiánya növeli, hanem sokkal inkább a lecsúszástól, a státusvesztéstől való félelem, mint arra Messing Vera és Ságvári Bence felhívták a figyelmet. A szerzőpáros 2016-ban megjelent tanulmányában a létfenntartásért, valamint az alsó-középosztálybeli társadalmi pozícióik megőrzéséért folytatott küzdelem mellett fontos tényezőként említik a magyar oktatási rendszer néhány sajátosságát: az oktatás szelektív jellegét, és az annak következtében létrejövő homogén iskolai környezetet, a hagyományos, tananyag-orientált pedagógiai gyakorlatokat, valamint az állandó versenyhelyzetre építő módszereket, amelyek közvetett vagy akár közvetlen formában mind hozzájárulnak a kirekesztő attitűdök gyermekkorban történő kialakulásához és későbbi megőrzéséhez (Messing és Ságvári, 2016).

Az idegenellenesség elemzésénél fontos figyelembe venni továbbá a bevándorlással kapcsolatos félelmeket is, amelyekre külön kitért a fentebb hivatkozott CEORG-kutatás. A 2015-ben folytatott adatgyűjtés során nyolc állitáson keresztül mérték a bevándorlással kapcsolatos félelmeket, és ezen állításokat három csoportba osztották. A magyarországi válaszadók a konkrét félelmek közül a bevándorlók lojalitására (62\%), az elvont félelmek közül a bevándorlás mértékének ellenőrizhetetlenné válására (53\%), míg a jóléti sovinizmussal összefüggő félelmek közül az életmóddal kapcsolatos fenyegetettségre, azaz a társadalmi szempontra (55\%) vonatkozó állításokat jelölték meg a legnagyobb arányban (8. ábra). 


\section{8. ábra: A bevándorlással kapcsolatos félelmek Magyarországon 2015-ben}

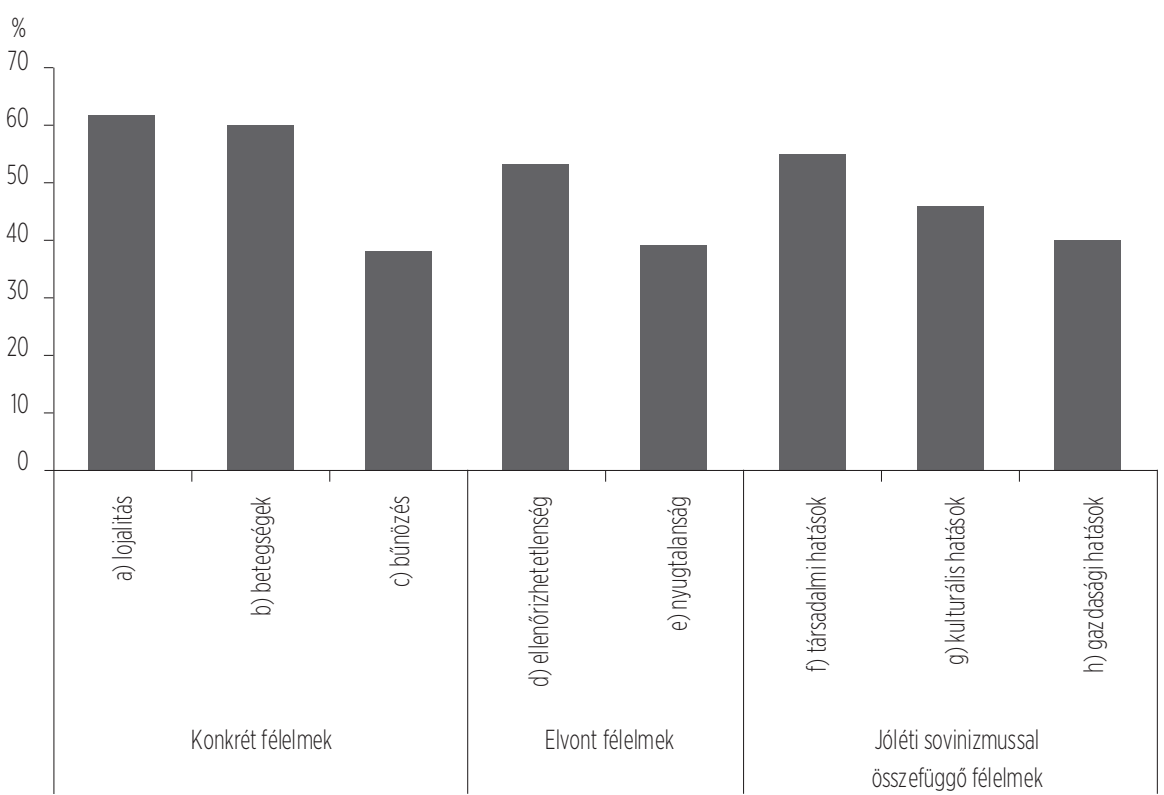

Forrás: CEORG-adatfelvételek, 2015. Sik et al., 2016, 102-103. o. F1. táblázat: A félelmet mérő kérdéssor alapmegoszlásai százalékban ( $\mathrm{N}=1003){ }^{6}$

Végezetül fontos hangsúlyozni, hogy az idegenellenesség magas értéke nem hazai specialitás, hanem az egész kelet-közép-európai régióra jellemző, mint azt számos kutatás kimutatta. Ezek közül az egyik legkiemelkedőbb a majd húsz évre és több mint húsz országra kiterjedő International Social Survey Programme (ISSP), amelynek keretében az idegenellenességet kilenc állításon keresztül mérték. Egyes állítások negatív, míg mások pozitív ítéleteket fogalmaz-

\footnotetext{
${ }^{6}$ Az ábrán azoknak a magyarországi válaszadóknak az aránya jelenik meg, akik „egyetértettek”, illetve „teljes mértékben egyetértettek" a CEORG 2015-ös adatfelvétele során a bevándorlással kapcsolatos félelmek méréséhez alkalmazott, három csoportra osztott, nyolc állitással. 1.) A konkrét félelmekre vonatkozó állitások: a) attól tartok, hogy háború vagy más politikai feszültség esetén a bevándorlók a származási országukhoz lesznek inkább lojálisak; b) aggódom amiatt, hogy a bevándorlók ismeretlen betegségeket terjeszthetnek; c) a bevándorlók miatt növekszik a bünözés Magyarországon. 2.) Az elvont félelmekre vonatkozó állitások: d) a bevándorlás mértéke Magyarországon ellenőrizhetetlenné vált; e) nyugtalanná válok, ha bevándorlókkal kerülök kapcsolatba. 3.) A jóléti sovinizmussal összefüggő félelmekre vonatkozó állitások: f) attól tartok, hogy a bevándorlók számának növekedése rossz irányba változtatja az életmódunkat; g) attól tartok, hogy a bevándorlók számának növekedése miatt el fog veszni a mi saját kultúránk; $h$ ) a bevándorlók olyan emberek elöl veszik el a munkát, akik már régebb óta itt élnek.
} 
tak meg a bevándorlókkal szemben.7 Az összehasonlítás alapját ezen állítások elfogadásának a gyakorisága adta. Az időbeli trendeket is figyelembe véve ennek a kutatássorozatnak az eredményei is azt mutatják, hogy a bevándorlókkal szembeni negatív attitűdök a kelet-közép-európai országokban erőteljesebben nyilvánulnak meg, mint a kontinens nyugati, északi és déli régióiban (9. ábra).

\section{9. ábra: Az idegenellenesség mértékének alakulása Európában}

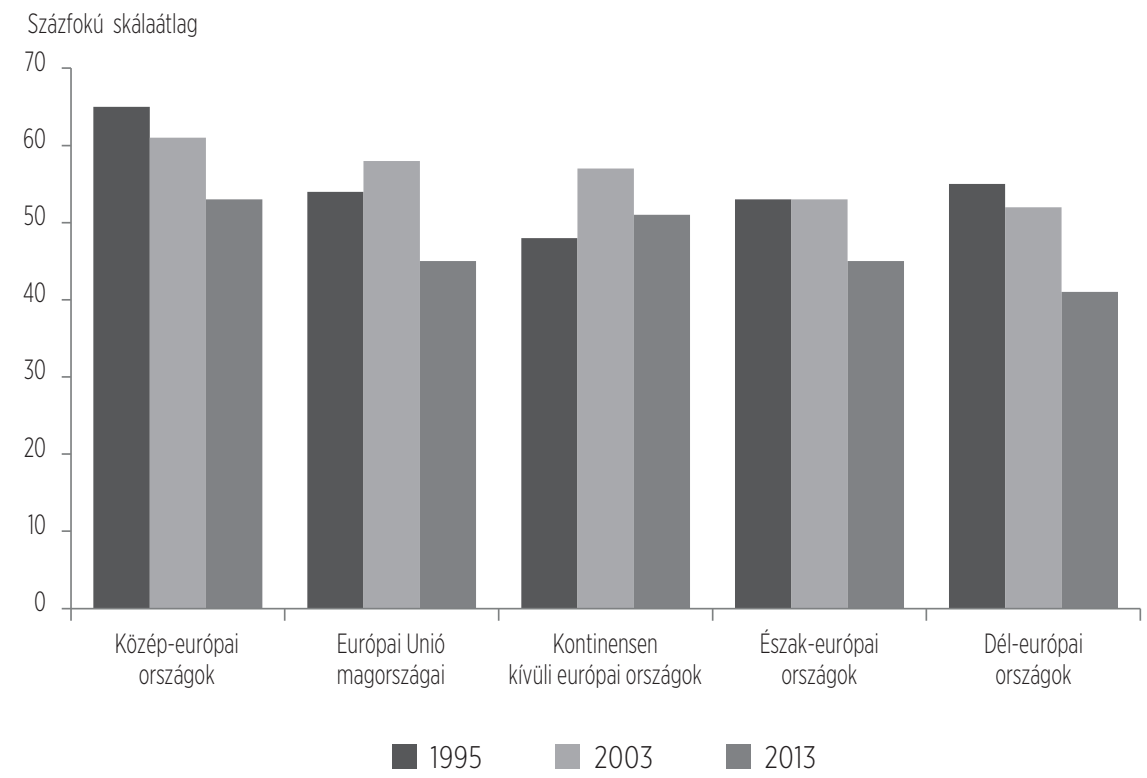

Forrás: Csepeli és Örkény, 2017, 57. 0.8

A fenti kutatás eredményeire reflektálva Csepeli György és Örkény Antal Nemzet és migráció címen 2017-ben megjelent kötetükben azt írták: „Európa nyugati

\footnotetext{
${ }^{7}$ A ISSP-kutatás során a idegenellenesség méréséhez alkalmazott kilenc állitás a következő volt: 1.) az országnak növelni kellene a bevándorlók számát; 2.) a legális bevándorlóknak ugyanolyan hozzáférést kell biztosítani a közoktatáshoz; 3.) az országnak szigorúbb intézkedéseket kell hoznia az illegális bevándorlás megakadályozására; 4.) a legális bevándorlóknak ugyanazon jogok járnak, mint az ország állampolgárainak; 5.) a bevándorlók aláássák az ország kultúráját; 6.) a bevándorlók nyitottabbá teszik az országot az új eszmék és kultúrák iránt; 7.) a bevándorlók elveszik a munkát azok elöl, akik az országban születtek; 8.) a bevándorlók hasznára válnak a gazdaságnak; 9.) a bevándorlók miatt növekszik a bünözés (Csepeli és Örkény, 2017, 56. 0.).

${ }^{8}$ Az ISSP-kutatássorozat eredményeire alapozott ábrán megjelenített nagyrégiók a következő országokra vonatkoznak: 1.) közép-európai országok: Csehország, Észtország, Horvátország, Lettország, Litvánia, Magyarország, Szlovákia, Szlovénia; 2.) az Európai Unió magországai: Belgium, Franciaország, Németország; 3.) a kontinensen kívüli európai országok: Nagy Britannia, Írország (elemzésemben ez utóbbi két nagyrégiót hívom egybevontan Nyugat-Európának); 4.) észak-európai országok: Dánia, Finnország, Izland, Svédország, Norvégia. 5.) dél-európai országok: Portugália, Spanyolország.
} 
és keleti régióiban a másság elutasitásának érzülete egyaránt jelen van, csak a másságra adott reagálás módja különböző. Keleten az asszimilációt lehetetlennek tartó nyílt xenofóbia, Nyugaton az asszimilációs elvárásba bújtatott burkolt xenofóbia jellemző" (Csepeli és Örkény, 2017, 60. o.). Mindez a történelmi tapasztalatok figyelembevételével kiegészithető azzal, hogy a többnyire külföldi nyomásra kialakult politikai ideológiák és rendszerek - a kommunizmus eszméjére alapozott államszocializmus, illetve a liberalizmusra épített globálkapitalizmus - összeomlása vagy esetleges megingása esetén a kelet-közép-európai országok többségi társadalmai szokás szerint befelé fordulnak. A vezetőik eredetmítoszok és kreált ellenségképek árnyékában igyekeznek a nemzetegyesítés zászlóvivőiként feltűnni, amely még mindig a társadalmi fejlődés és a válsághelyzetből való kilábalás egyetlen biztos útjaként jelenik meg a köztudatban. Mindez a nacionalizmus térnyerésével és az idegenekkel szembeni negatív attitüdök - a gyanakvás, a félelem, illetve az abból fakadó harag és gyűlölet - felerősödésével jár együtt. Ez tapasztalható volt a kétpólusú világrendszer megszűnése után, az 1989-1991-es rendszerváltások folyamataiban, valamint a 2008-2009-es világgazdasági válságot követően, amit a 2014-2015-ös menekülthullám tovább fokozott. A tőke és az emberek szabad mozgásának lehetőséget adó liberalizmusból való kiábrándulás újra divatba hozta a nemzeteszméket és a határfalakat.

\section{KI- ÉS VISSZAVÁNDORLÁS}

Az alkalmazott módszerek sokfélesége miatt igen eltérő kutatási eredmények születtek arról, hogy az 1989-es rendszerváltás óta kik, hányan, mikor és hova vándoroltak el Magyarországról. E tekintetben - mint a bevezetőben már említettem - a kibocsátó országok adatai általában pontatlanabbak a befogadó országok adatainál. Következésképpen az 1. ábrán feltüntetett magyarországi statisztikák kivándorlási adatainál jóval magasabb értékeket mutatnak a magyar emigránsokat befogadó országok bevándorlási és munkaügyi statisztikái. ${ }^{9}$

\footnotetext{
${ }^{9}$ A ki- és visszavándorlásra vonatkozó hazai adatok forrása az Országos Egészségbiztosítási Pénztár (OEP) - 2017-től a Nemzeti Egészségbiztosítási Alapkezelő (NEAK) - külföldön munkavállalók biztosítási nyilvántartása (KÜLFI), amely a TAJ-számok átmeneti érvénytelenítését kezeli. A külföldön biztosított személyek magyarországi egészségbiztosítási pénztár nyilvántartásából való kijelentkezését a kötelező egészségbiztosítás ellátásairól szóló 1997. évi LXXXIII. törvény 80. § (5) a következőképp írja elő: „Az a TAJ-számmal rendelkező személy, aki valamely EGT-tagállamban, illetve Svájcban, valamint a Magyarország által kötött nemzetközi egyezmény hatálya alá tartozó államban biztosított, [...] köteles a külföldön, illetve a nemzetközi szervezet szociális biztonsági rendszerében létrejött biztosítását és annak megszűnését 15 napon belül bejelenteni az egészségbiztosítónak." A törvény teljes szövege elérhető a net.jogtar.hu weboldalon.
} 
Utóbbiakat illetően 2013 és 2015 között évi több mint 85 ezer bevándorló magyar állampolgárt regisztráltak csak az európai célországokban (10. ábra).

10. ábra: A magyar emigráció az ezredfordulót követően - hazai statisztikák vs. tükörstatisztikák

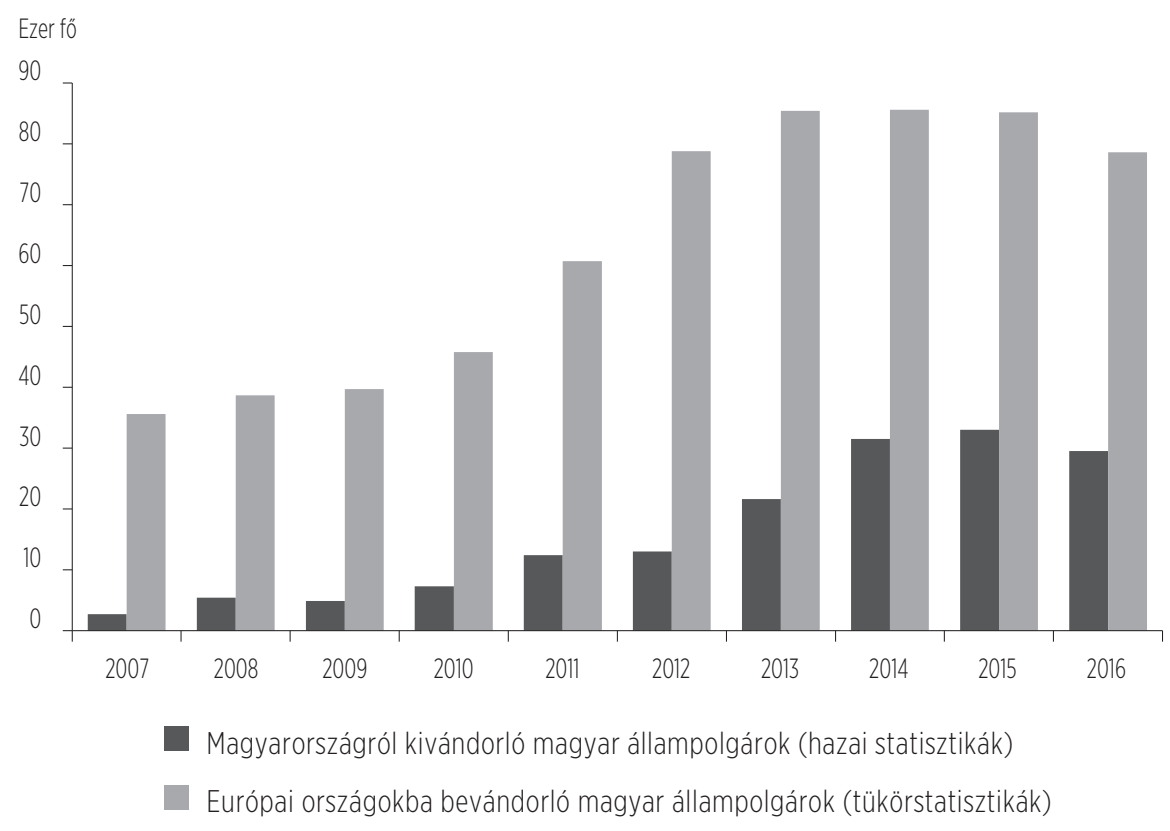

Forrás: Gödri, 2018, 254. 0.10

Magyarországon az Európai Unióhoz való csatlakozást nem követte az elvándorlás olyan mértékű fellendülése, mint a környező országok többségében (csupán Csehország és Szlovénia esetében volt alacsonyabb szintű a kiáramlás). Az emigráció csak a 2000-es évek második felében - kiváltképp a 2008-as gazdasági válság kirobbanását követően - kezdett el felélénkülni, mely folyamat 2010 után felgyorsult (Lakatos, 2015). A hazai statisztikák alapján a legalább egy évre külföldre költözött magyar állampolgárok száma 2010-ben alig haladta meg a hétezer főt, 2012-ben majd 13 ezer fő, 2013-ban több mint 21 ezer fő, 2014-ben több mint 31 ezer fö, míg 2015-ben majd 33 ezer fő volt. A tükörstatisztikák (10. ábra) ennél jóval magasabb értékeket mutatnak. Mindkét forrás - ugyan jelentős

\footnotetext{
${ }^{10} \mathrm{Az}$ ábrán az Eurostat-adatbázis, a németországi (DESTATIS-) és ausztriai (Statistik Austria-) statisztikák, valamint a KSH Demográfiai évkönyvei alapján végzett számítások eredményei jelennek meg. Adathiány miatt az Egyesült Királyság 2006-tól, valamint Franciaország 2012-ig nem szerepel az összesítésben.
} 
számbéli eltéréssel - megegyezik abban, hogy az elvándorlás növekedésének üteme 2014-ben mérséklődni kezdett, majd rövid ideig stagnált, 2016-tól pedig csökkenő tendenciát mutat.

A 2010-es években fellendült emigrációs hullámmal külföldre vándorolt magyarok többsége fiatal (háromnegyedük a 40 éves kort sem érte el, több mint 40\%-uk 30 év alatti), több mint fele (53-54\%) férfi, közülük sokan (63-64\%) nőtlenek, hajadonok voltak (KSH, Népmozgalom, statisztikai tükör [éves elemzések]; Blaskó és Gödri, 2016). A magyarországi összlakossághoz viszonyítva továbbá jóval magasabb (18\% vs. 32\%) volt közöttük a diplomások aránya. A „fiatalok exodusának” is nevezett új magyar emigráció nemcsak közvetlen, de közvetve is hatott a hazai népesedési folyamatokra: a népességfogyás és a korszerkezet átalakulásának fokozása mellett negatívan befolyásolta a hazai termékenységi rátát. 2010 és 2016 között mintegy 78 ezer külföldön született gyermek hazai anyakönyvezését kérték magyar állampolgárságú szüleik (Gödri, 2018).

A kivándorlás ütemének felgyorsulásával a hagyományosnak nevezhető célországok, Németország és Ausztria mellett megjelent számos új desztináció is, melyek közül kiemelt jelentőségü az Egyesült Királyság. A tükörstatisztikák szerint 2017 elején az EGT országaiban élő több mint 461 ezer magyar állampolgár háromnegyede a fent említett három célországban élt. Az erre vonatkozó adatok időbeli alakulása jól tükrözi a magyar emigránsok számbeli növekedését. Az Eurostat adatbázisa szerint 2001 és 2017 között Németországban 54 ezerről 80 ezer főre, Ausztriában kevesebb mint 13 ezerről több mint 70 ezer főre, míg az Egyesült Királyságban alig több mint négyezerről 96 ezer főre nőtt a huzamosan ott élő magyar állampolgárok száma. Ez utóbbit illetően egyes források még ennél is többre, 300-400 ezer főre becsülik a szigetországban élő magyarok összlétszámát, ebből a feltevések szerint csak Londonban 100-130 ezer fő él (Gödri, 2018), ami meghaladja Székesfehérvár összlakosságát. E magas értékeket elsősorban az Egyesült Királyságban kibocsátott társadalombiztosítási szám, az ún. National Insurance Number (NINo) alapján határozzák meg, amit az öszszes olyan külföldi állampolgárnak ki kell váltania, aki legálisan szeretne munkát vállalni az országban. 2004 és 2017 között közel 220 ezer magyar állampolgár kapott ilyen számot (köztük e sorok írója is). Ezekről a személyekről azonban nem ismert, hogy mennyi ideje élnek a szigetországban, de feltételezhető, hogy közülük sokan csak ideiglenes munkavállalás céljából vándoroltak be, és egy éven belül tovább is álltak, így szigorú értelemben véve - az ENSZ nemzetközi vándorlás méréséről szóló 1998. évi ajánlására alapozott fenti meghatározás szerint - nem számítanak bevándorlónak. Ennek ellenére a NINo gyakran még a 
szakirodalomban is az Egyesült Királyságba irányuló, gazdasági célú bevándorlás par excellence mutatójaként jelenik meg (Moreh, 2017).

Az említett három fő célországban élő magyar állampolgárok demográfiai összetételében jelentős különbségek figyelhetők meg. A KSH 2016 októbernovemberében a hazai háztartások 10\%-os mintáján végrehajtott mikrocenzus nemzetközi vándorlásra vonatkozó adatai szerint a Németországba vándorlók csoportját többnyire idősebb (40-64 éves), alapfokú és szakmunkás végzettséggel rendelkező férfiak alkotják. Németország és Ausztria továbbá főként a rövidebb távra kivándorlók körében népszerü. Ezzel szemben az Egyesült Királyság jobban vonzza a huzamosabb ideig külföldön élő, érettségivel, illetve diplomával rendelkező fiatalokat (KSH, 2018). Hasonló eredményre jutott a SEEMIG - Managing Migration in South East Europe - transznacionális együttműködési projekt keretében megvalósuló nemzetközi migrációkutatás, mely szerint a szigetországba vándorló magyar állampolgárok átlagéletkora a 2013as adatfelvételkor 33 év volt, kiköltözésük pillanatában pedig mindössze 29 évesek voltak (SEEMIG, 2014). A magyar emigráció ütemének mérséklődésével az Egyesült Királyságba vándorló magyar állampolgárok száma is csökkent, ami a Brexit hatására tovább fokozódott (Gödri, 2018).

A 2010-es évek elején tömegessé vált elvándorlás okai összetettek, de mint azt korábban is jeleztem, az új magyar emigráció lényegében gazdasági jellegü, tehát a migrációs szándékok mögött többnyire munkával, bérekkel, megélhetéssel kapcsolatos motivációk állnak (Gödri, 2016; Hárs és Simon, 2017; Hárs, 2020). A taszító tényezők között kiemelt szerepe volt az eleve deficitekkel küzdő hazai gazdaság világválság következtében történő tovább romlása, és vele együtt a munkaerőpiac hanyatlása. Magyarországon 2009 és 2013 között a 20-24 évesek körében 25\% körüli volt a munkanélküliségi ráta, ami európai viszonylatban kiugróan magas értéknek számított (Gödri, 2018). A hazai gazdasági problémák felerősödésével egy időben a válságból kilábaló nyugat-európai országok sorra oldották fel munkaerőpiaci korlátozásaikat az Európai Unióhoz a 2000-es évek folyamán csatlakozott tagországok állampolgárai előtt." Az így létrejövő új munkalehetőségek jelentették a legnagyobb vonzerőt a Kelet-Európából NyugatEurópába vándorlók számára. Az új magyar emigráció gazdasági jellegére több kutatás is nagy hangsúlyt fektetett. Idesorolható az a majd tízezer mintás kérdőives felmérés, amit a Miskolci Egyetem Földrajz-Geoinformatika Intézetének

\footnotetext{
"Az új tagországok polgárai előtt az Egyesült Királyság, Írország és Svédország már az Európai Unióhoz való csatlakozás pillanatában megnyitották munkapiacukat. Olaszország és Spanyolország 2006-ban, Hollandia 2007-ben, Németország, Ausztria és Svájc 2011-ben tették ugyanezt. (Gödri, 2018, 257. 0.)
} 
munkatársai végeztek 2013 és 2016 között a magyar fiatalok körében (Siskáné Szilasi et al., 2017). A beérkező válaszok alapján a kivándorlási szándékot és a célországválasztást meghatározó vonzó és taszító tényezőket a következő rangsorban határozták meg (11. ábra).

11. ábra: A kivándorlási szándékot és a célországválasztást meghatározó vonzó és taszitó tényezők

Taszító tényezők

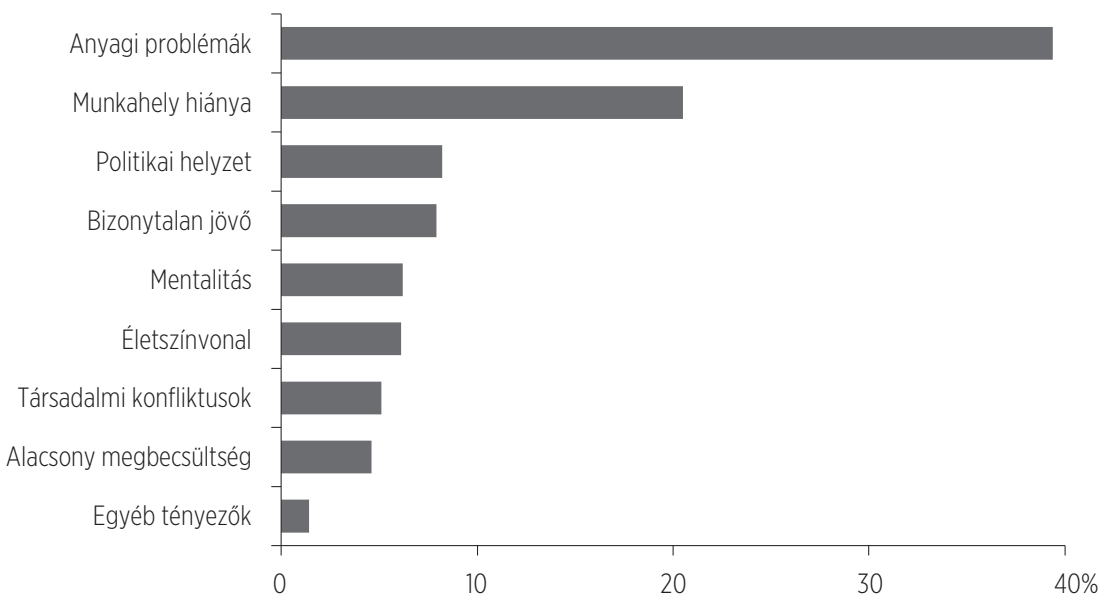

Vonzó tényezők

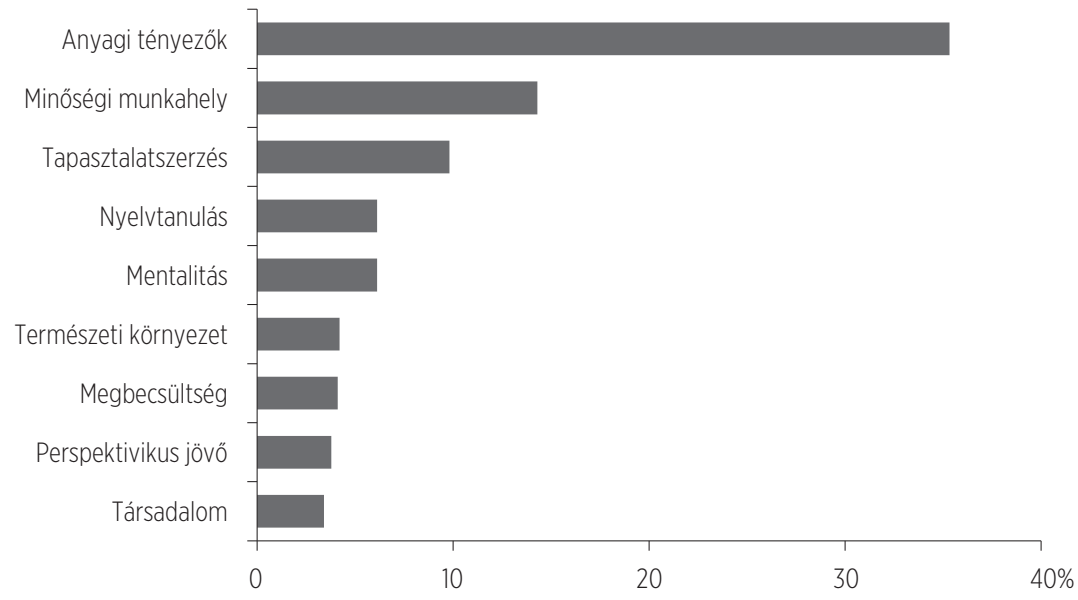

Forrás: Siskáné Szilasi et al., 2017, 141. 0. 
Hasonló eredményre jutottak az MTA Társadalomtudományi Kutatóközpont Kisebbségkutató Intézetének munkatársai, akik a Nagy-Britanniában élő magyar fiatalok körében folytattak online kérdőíves kutatást 2014 tavaszán (Kováts és Papp Z., 2016). A többségében 2010 után kivándorolt, szigetországban élő 5200 magyar emigráns válaszadó több mint háromnegyede dolgozni ment ki. Közel fele-fele arányban voltak, akik konkrét munkaajánlatra érkeztek, és akik csak a kiutazásuk után kezdtek el munkát keresni. A válaszadók több mint felénél fontos szempont volt a rossz gazdasági helyzet Magyarországon, míg a magasabb életszínvonal és a jobb munkalehetőségek Nagy-Britanniában. A politikai helyzet miatti távozást és a szakmai fejlődés lehetőségét kevesebben, de azért számottevően említették. Az ezektől eltérő migrációs okok - mint a kíváncsiság, kalandvágy vagy magánéleti problémák - jóval kisebb arányban, a válaszadók alig több mint egyötödénél bizonyultak fontosnak. A megkérdezettek elsöprő többsége elégedett volt a jelenlegi helyzetével, különösen, ha a korábbi, magyarországi körülményeivel hasonlította össze azt. Alig több mint egytizedük érezte úgy, hogy a helyzete nem javult, vagy rosszabbodott, amióta Nagy-Britanniában él. Többségük éppen ezért nem tervezte a közeljövőben a Magyarországra való visszatérést: közel háromnegyedük soha, vagy a következő öt évben biztosan nem tért volna vissza. Az ilyen jövőbeli elképzelések persze nagyon képlékenyek, a körülmények alakulásával gyorsan változhatnak.

Egy későbbi, 2018-2019-ben megvalósított, szintén online adatgyűjtésen alapuló kutatás eredményei is a gazdasági, munkaerőpiaci tényezők jelentőségét hangsúlyozták a kivándorlási szándékot illetően (Hárs, 2020). A megközelítőleg 1400, Magyarországon született, legalább három hónapja külföldön élő, 18 évesnél idősebb válaszadót - többszörös válaszlehetőség mellett, a válaszok gyakorisága alapján - 65\%-ban a magasabb jövedelem reménye, 40\%-ban az itthoni munkalehetőségek hiánya, 20\%-ban a konkrét anyagi gondok hajtották külföldre. 37\%-uk érezte fontosnak továbbá az itthoni politikai hangulatot, 20\%uk pedig a gyerekek iskoláztatásának, jövőjének a jobb lehetőségét.

A 2016. évi mikrocenzus eredményei is azt támasztják alá, hogy a 2010-es évek első felében kivándoroltak leginkább munkavállalás céljából hagyták el az országot. A kis népszámlálás adatai alapján a külföldön élők 86, a visszavándorlók 66, míg a kivándorlást tervezők 89\%-a elsősorban dolgozott, illetve dolgozni szeretett volna külföldön.

A kivándorlás motivációinak ismertetése után a külföldi munkavállalás milyenségére fókuszálva - továbbra is a 2016. évi mikrocenzus eredményeire támaszkodva - azt látjuk, hogy a külföldön élő munkavállalók és a külföldi munkatapasztalattal rendelkezők foglalkozásai közül három foglalkozási főcso- 
port aránya emelkedik ki: a kereskedelmi-szolgáltatási (egyaránt 23\%), az ipariépítőipari (21, illetve 22\%), valamint a szakképzettséget nem igénylő foglalkozások (15, illetve 18\%). Ezek az arányszámok jelentősen eltérnek a hazaitól, hiszen míg a 16-64 éves magyar lakosság csupán 39\%-a dolgozik ezen a három területen, addig a fenti adatok szerint a külföldön élök 59, a visszavándorlók 63\%a ezekhez köti külföldi munkatapasztalatát. A 2016. évi mikrocenzus adataiból továbbá kiderül, hogy a kivándorlást tervezők kevesebb mint egyharmada (29\%) hagyná el véglegesen az országot, míg közel fele (47\%) legfeljebb öt évre menne el, 13\%-uk pedig egy éven belül visszajönne Magyarországra (KSH, 2018). Ez is alátámasztja azt a bevezetőben tett állapítást, miszerint a gazdasági emigrációról való elképzelések sok esetben nem az ország végleges elhagyására irányulnak, hanem az ideiglenes külföldi munkavállalásra, amely magában hordozza a későbbi hazaköltözés reményét.

Az elvándorlás ütemének mérséklődése mellett a 2010-es évek második felére egyre több külföldön élő magyar állampolgár költözött vissza Magyarországra. ${ }^{12} 2015$ és 2019 között a kivándorlók száma a kétharmadára csökkent (közel 33 ezerről kevesebb mint 22 ezerre), míg a visszavándorlók száma bő másfélszeresére nőtt (kevesebb mint 15 ezerről több mint 23 ezerre), mely az évtized végére trendfordulót eredményezett: 2019-ben a hazai statisztikák szerint több Magyarországon született magyar állampolgár költözött vissza, mint ahány elment (12. ábra).

A visszavándorlás eseménye azonban még nem jelenti a tényleges hazaköltözést. A visszavándorlók ugyanis idővel újra elvándorolhatnak, vagy cirkuláris migrációt is folytathatnak. Ez utóbbi ráadásul igen gyakori jelenség, különösen a közelebbi országokban, főképp Ausztriában és Németországban munkát vállaló magyar állampolgárok körében. A visszavándorlásról éppen ezért pontosabb képet nyújtanak azok a kutatások, amelyek indirekt módszerek alkalmazásával nem a külföldről hazatérőkre, hanem a migrációs tapasztalatokkal rendelkező hazai népességre összpontosítanak. Idesorolható a már többször említett 2016. évi mikrocenzus, amelynek eredményei szerint a Magyarországon született honos népesség 2,6\%-ának, összesen 242 ezer főnek volt legalább egyéves migrációs tapasztalata az adatfelvétel időpontjában. A visszavándor-

\footnotetext{
${ }^{12}$ Magyarországon a visszavándorlás méréséhez használt hivatalos adatforrás - a kivándorláshoz hasonlóan - a NEAK adatbázisa. A hazai statisztikák a bejelentési kötelezettségüknek eleget tevő migránsok közül azokat a magyar állampolgárokat tekintik visszavándorlóknak, akik Magyarországon születtek, és legalább egy évig folyamatosan Magyarország mai területén kivül tartózkodtak, de az adott, rájuk vonatkozó felmérés időpontjában már Magyarországon éltek. Ezt a szükebb, születési helyet is figyelembe vevő meghatározást az indokolja, hogy a visszavándorlók definíciójába ne kerüljenek bele azok a határon túli, honositással magyar állampolgárságot szerzett magyarok, akik valamely szomszédos országban születtek, és onnan költöztek Magyarországra (KSH, 2018).
} 
lás okai ugyan mutatnak némi különbséget a külföldi tartózkodás időtartama, elsődleges célja, valamint a kivándoroltak iskolai végzettsége szerint, azonban általánosan elmondható, hogy e tekintetben a családi okok a meghatározóak. A legalább egy évig külföldön élők közel fele ezekkel indokolta a hazaköltözését. A visszavándorlók 57\%-a a jelenkori magyar emigráció három legfőbb célországából, Németországból, Ausztriából és az Egyesült Királyságból tért vissza, 28\%-a az EGT más tagállamaiból, 6,8\%-a pedig az Amerikai Egyesült Államokból. Míg a 2010-es években fellendült emigráció hatása leginkább DélDunántúlon érezhető, a visszavándorlók körében a Közép-Magyarországon élők aránya kiugró (KSH, 2018).

12. ábra: A ki- és visszavándorlás alakulása Magyarországon a 2010-es évek közepétől

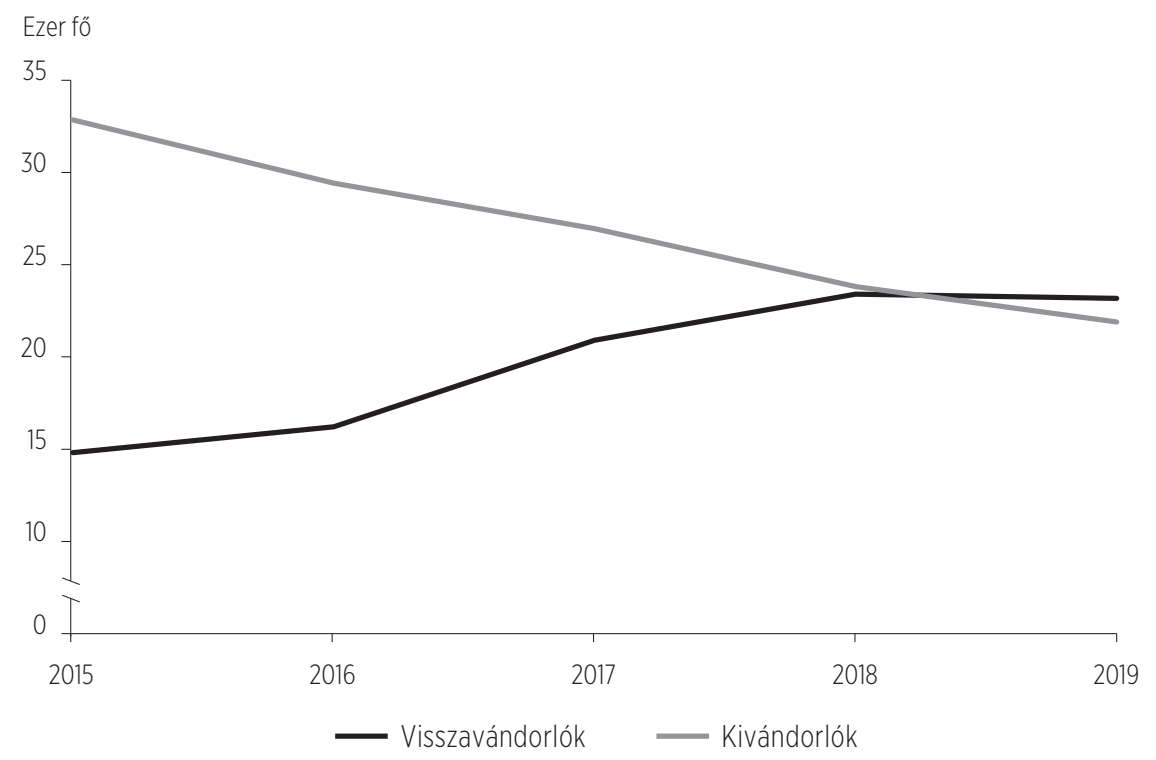

Forrás: KSH, STADAT-táblák.

\section{KÖVETKEZTETÉSEK}

A migrációkutatás módszertani korlátai, a célcsoportok esetlegesen ismétlődő helyváltoztatása és belső heterogenitása miatt nehéz általános és reális képet nyújtani a jelenkori magyar társadalmat érintő népvándorlás folyamatairól. A meglévő statisztikai adatokból és kutatási eredményekből látszólag egymásnak 
ellentmondó következtetések is levonhatóak, holott valójában a népvándorlással kapcsolatos ismeretek különböző aspektusairól van szó. A kivándorlást illetően egyrészt a nagymintás felmérésekből kimutatható, hogy a 2010-es években főképp gazdasági okok miatt külföldre vándorolt magyar fiatalok többsége elégedett a helyzetével, és nem tervez hazaköltözni a közeljövőben. Másrészt a hivatalos statisztikai adatok alapján megállapítható az is, hogy az évtized végére elsősorban családi okok miatt többen vándoroltak vissza Magyarországra, mint ahányan elmentek. A bevándorlást illetően pedig épp annyira hangsúlyozandó, hogy az elmúlt évtizedben az országba érkező külföldi állampolgárok száma jelentősen megnőtt, és ezzel együtt a származás szerinti összetétele diverzifikálódott, mint hogy a tartózkodásra vagy letelepedésre jogosító engedélyt, illetve menekült, oltalmazott vagy befogadott státust kapott migránsok népességhez viszonyított aránya messze elmarad az európai átlagtól. Összességében véve a migrációs folyamatok jelentős demográfiai változást nem idéztek elő Magyarországon. Utóbbi állítás kiegészítéseként megjegyzendő, hogy 2017-ben - tehát a Közel-Keletről a Nyugat felé tartó menekülthullám felerősödése után, de még az ukrán bevándorlás tömegessé válása előtt - az összesen 521 ezer fős külföldi kötődésű lakosságból 338 ezer fő a szomszédos négy ország, Románia, Szerbia, Ukrajna és Szlovákia valamelyikéből származott. Mindez rávilágít a migráció összetett, többdimenziós és dinamikusan változó természetére.

A népvándorlás társadalmi, gazdasági és kulturális hatásainak vizsgálatánál nem hagyható figyelmen kívül továbbá a célcsoportok cirkuláris mozgása, valamint letelepedésük esetén a többségi társadalomhoz való viszonyulása. Utóbbi ugyan túlmutat a szűkebb értelemben vett migrációkutatás keretein, és inkább a diaszpórakutatáshoz közelít, így a jelenkori magyar társadalmat érintő migrációs folyamatok elemzése során nem is tértem ki rá, tanulmányom zárásaként azonban elengedhetetlennek tartom hangsúlyozni, hogy a bevándorlás, még ha tömeges méretet is ölt, nem feltétlenül vezet diaszpórikus közösségek kialakulásához, mint ahogyan a kivándorlás sem feltétlenül gyarapítja az anyaország határain kívül élő nemzetrészeket. A migránsokról ugyanis még nem tudhatjuk, hogy az őket befogadó ország társadalmába integrálódnak-e, vagy tovább vándorolnak, esetleg idővel hazaköltöznek, illetve hogy helyben maradásuk esetén törekednek-e az etnikai határok megtartására, vagy a társadalmi beilleszkedés folyamatában kulturálisan is asszimilálódnak (Gazsó, 2015). A kivándorlással, bevándorlással és menekültüggyel kapcsolatos tévhitek és félelmek leküzdéséhez a statisztikai számadatok mellett e folyamatok hosszú távú nyomon követése is szükséges. Ezek részletes ismertetése azonban már egy újabb tanulmányt igényel. 


\section{IRODALOM}

Barna I. és Koltai J. (2018): A bevándorlókkal kapcsolatos attitűdök belső szerkezete és az attitűdök változása 2002 és 2015 között Magyarországon a European Social Survey (ESS) adatai alapján. Társadalomtudományi szemle, 8(2), 4-23.

Blaskó Zs. és Gödri I. (2016): A Magyarországról kivándorlók társadalmi és demográfiai összetétele. In Blaskó Zs. és Fazekas K. (szerk.): Munkaeröpiaci Tükör 2015 (59-67. o.). Budapest: MTA Közgazdaság- és Regionális Tudományi Kutatóközpont Közgazdaságtudományi Intézet.

Blaskó Zs., Sik E. és Ligeti A. S. (2014): Magyarok külföldön. Mennyien? Kik? Hol? In Kolosi T. és Tóth I. Gy. (szerk.), Társadalmi Riport 2014 (351-372. o.). Budapest: TÁRKI.

Csepeli Gy. és Örkény A. (2017): Nemzet és migráció. Budapest: ELTE Társadalomtudományi Kar.

Eurostat (2018): Migration and migrant population statistics. Statistics explained [Data extracted in March 2018]. Elérhető: ec.europa.eu/eurostat/statistics-explained

Eurostat (2020): Residence permits. Statistics on first permits issued during the year [Data extracted in November 2020]. Elérhető: ec.europa.eu/eurostat/statistics-explained

Ferenc V. és Kovály K. (szerk.) (2020): Kárpátalja mozgásban: társadalmi változások és interetnikus viszonyok az Euromajdan után. Budapest: Bethlen Gábor Alapkezelő Zrt.

Gazsó D. (2015): Egy definíció a diaszpórakutatás margójára. Kisebbségkutatás, 24(2), 7-33.

Gödri I. (2015): Nemzetközi vándorlás. In Monostori J., Őri P. és Spéder Zs. (szerk.): Demográfiai portré 2015. Jelentés a magyar népesség helyzetéröl (187-211. o.). Budapest: KSH Népességtudományi Kutatóintézet.

Gödri I. (2016): Elvándorlási szándékok - Álmok és konkrét tervek között. A migrációs potenciál jellemzői és meghatározó tényezői a 18-40 évesek körében Magyarországon (KSH Népességtudományi Kutatóintézet Kutatási Jelentések 98). Budapest: 2016. KSH Népességtudományi Kutatóintézet.

Gödri I. (2017): Az integráció mutatói és esélykülönbségei a Magyarországon élő bevándorlók körében. Demográfia, 60(1), 5-55.

Gödri I. (2018): Nemzetközi vándorlás. In Monostori J., Őri P. és Spéder Zs. (szerk.): Demográfiai portré 2018. Jelentés a magyar népesség helyzetéröl (237-270. 0.). Budapest: KSH Népességtudományi Kutatóintézet.

Hárs Á. (2020): Elvándorlás, visszavándorlás, bevándorlás. Jelenségek és munkaerőpiaci hatások. In Kolosi T., Szelényi I. és Tóth I. Gy. (szerk.): Társadalmi Riport 2020 (115-145. o.). Budapest: TÁRKI.

Hárs Á. és Simon D. (2017): A külföldi munkavállalás és a munkaerőhiány. In Fazekas K. és Köllő J. (szerk.): Munkaerőpiaci Tükör 2016 (94-108). Budapest: MTA Közgazdaság- és Regionális Tudományi Kutatóközpont Közgazdaságtudományi Intézet.

Kapitány B. és Rohr A. (2014): Kivándorlás Magyarországról - egy új becslési eljárás eredményei. In Spéder Zs. (szerk.), A család vonzásában. Tanulmányok Pongrácz Tiborné tiszteletére (67-84. o.). Budapest: KSH Népességtudományi Kutatóintézet.

Karácsonyi D. és Kincses Á. (2020): Átrendeződés? Kárpátaljaiak Magyarországon, magyarok Kárpátalján, a 2017-ig terjedő adatok tükrében. Területi Statisztika, 60(3), 309-351. 
Kincses Á. (2019): A Magyarországon élő külföldi kötődésű népesség területi jellegzetességei, 2011-2017. Területi Statisztika, 59(5), 463-497.

Kincses Á. és Tóth G. (2020): A szomszédos országokban született népesség területi mintázata Magyarországon, 2011, 2017. Területi Statisztika, 60(2), 155-178.

Kováts A. és Papp Z. A. (2016): Patterns of success amongst Hungarians living in the UK. Review of Sociology, 26(4), 95-123.

Kováts A. és Soltész B. (2018): Mit tudunk a kivándorlásról? Mühelybeszélgetések. Budapest: Gondolat Kiadó.

Kováts A. és Várhalmi Z. (Szerk.) (2014): A válaszhiányok kezelésétöl a résztvevő megfigyelésig: módszertani problémák a migrációkutatásban. Budapest: ICCR.

Központi Statisztikai Hivatal (2016): Menekültek a világban. Statisztikai tükör, 2016. július 25. Elérhető: www.ksh.hu

Központi Statisztikai Hivatal (2017): Új magyar állampolgárok. Változások az egyszerúsített honosítási eljárás bevezetése után. Elérhető: www.ksh.hu

Központi Statisztikai Hivatal (2018): Mikrocenzus 2016. Nemzetközi vándorlás. Elérhető: www.ksh.hu

Központi Statisztikai Hivatal, Demográfiai évkönyvek. Elérhető: www.ksh.hu

Központi Statisztikai Hivatal, STADAT-táblák. Elérhető: www.ksh.hu/stadat

Lakatos J. (2015): Külföldön dolgozó magyarok, Magyarországon dolgozó külföldiek. Statisztikai Szem/e, 93(2), 93-112.

Messing V. és Ságvári B. (2016): „Ahogy »másokhoz« viszonyulunk, az tükrözi azt, amilyenek magunk vagyunk" A magyarországi idegenellenesség okairól. Társadalomtudományi szem/e, 6(2), 17-37.

Moreh, C. (2017): Az Egyesült Királyságba irányuló magyarországi elvándorlás a magyar és a brit migrációs rendszerek átalakulásának tükrében. Ügyészségi Szemle, 2(3), 86-101.

SEEMIG (2014): Managing Migration in South East Europe transznacionális együttmúködési projekt. Helyzetkép a magyarországi elvándorlásról [sajtótájékoztató, 2014. október 15.]. Elérhető: www.ksh.hu

Sik E., Simonovits B. és Szeitl B. (2016): Az idegenellenesség alakulása és a bevándorlással kapcsolatos félelmek Magyarországon és a visegrádi országokban. Regio, 24(2), 81-108.

Siskáné Szilasi B., Halász L. és Gál-Szabó L. (2017): A magyar fiatalok erősödő kivándorlási szándékának kiváltó okai és jellemzői. Tér és Társadalom, 31(4), 131-147.

TÁRKI Omnibusz. Elérhető: www.tarki.hu

United Nations High Commissioner for Refugees (2014): Asylum Levels and Trends in Industrialized Countries. Elérhető: www.unhcr.org/statistics

United Nations (1951): Convention Relating to the Status of Refugees. Genf, 1951. július 28. Elérhető: unhcr.org

United Nations (1998): Recommendations on Statistics of International Migration. Revision 1, Statistical Papers, Series M, No. 58. Elérhető: unstats.un.org

Várhalmi Z. és Kováts A. (2014): Módszertani problémák a migrációkutatásban. In Kováts A. és Várhalmi Z. (szerk): A válaszhiányok kezelésétől a résztvevő megfigyelésig: módszertani problémák a migrációkutatásban (9-42. o.). Budapest: ICCR. 


\section{WHO IS A MIGRANT? CLARIFICATION OF THE MIGRATION PROCESS AFFECTING CONTEMPORARY HUNGARIAN SOCIETY}

\section{ABSTRACT}

During the past decade migration has become a central theme in Hungary. In addition to fears about the emigration of young and skilled people, its significance has been enhanced by the growing refugee crisis which hit its peak in the mid-2010s. Parallel to this development the concept of "migrant” has acquired a broader and more emotionally overheated meaning than ever before in public discourse. But, in fact, who is a migrant? Why have foreigners come to Hungary and where are they from? How many of them have actually settled in the country? What is their share of the general population, and how does this data compare to the international setting? How has the size and structure of the migration into Hungary evolved from the time of 1989 regime change to the present? When, why, and with what destination do Hungarian emigrants leave the country? How many have since returned? What are the sociodemographic features of the Hungarian emigrants? What are the major push and pull factors of emigration and remigration in Hungary? The present paper seeks answers to these questions. My goal is to provide an accurate picture of the ongoing migration trends in Hungary on the basis of both Hungarian and international data as well as the review of relevant studies that have been published about this issue. 